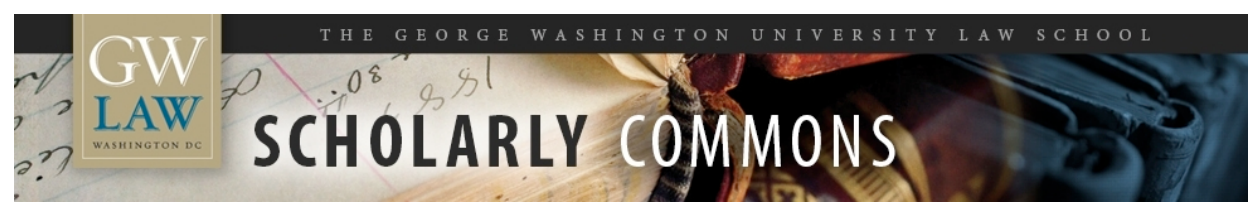

\title{
Towards a Cosmopolitan Vision of Conflict of Laws: Redefining Governmental Interests in a Global Era
}

Paul Schiff Berman

George Washington University Law School, pberman@law.gwu.edu

Follow this and additional works at: https://scholarship.law.gwu.edu/faculty_publications

Part of the Law Commons

\section{Recommended Citation}

153 U. Pa. L. Rev. 1819 (2005)

This Article is brought to you for free and open access by the Faculty Scholarship at Scholarly Commons. It has been accepted for inclusion in GW Law Faculty Publications \& Other Works by an authorized administrator of Scholarly Commons. For more information, please contact spagel@law.gwu.edu. 


\section{CHOICE OF LAW AND JURISDICTION ON THE INTERNET}

\section{TOWARDS A COSMOPOLITAN VISION OF CONFLICT OF LAWS: REDEFINING GOVERNMENTAL INTERESTS IN A GLOBAL ERA}

\section{PAUL SCHIFF BERMAN ${ }^{\dagger}$}

It has now been ten years since the idea of global online communication first entered the popular consciousness. And while the Internet has undoubtedly opened up new worlds of interaction and cooperation across borders, this increased transnational activity has also at times inspired parochialism, at least among the legislatures and courts of nation-states around the globe. Thus, we have seen a slew of national laws and court decisions purporting to regulate a wide variety of online activities, from gambling ${ }^{1}$ to chat rooms ${ }^{2}$ to auction sites, ${ }^{3}$

\footnotetext{
${ }^{\dagger}$ This paper was first presented at a Symposium on "Current Debates in the Conflict of Laws," held at the University of Pennsylvania Law School on November 12, 2004. I thank participants in that conference for their helpful comments, particularly Linda Silberman and Allan Stein, who offered especially thoughtful and extended advice. I also benefited greatly from the insights of my colleagues at an earlier workshop at the University of Connecticut School of Law, particularly Phillip Blumberg, Anne Dailey, Laura A. Dickinson, Mark A. Janis, Peter Siegelman, and Steven Wilf. Finally, I thank Patricia Bellia, Graeme Dinwoodie, Robert W. Gordon, Ved Nanda, and David Post for useful comments and criticisms, and I acknowledge the diligent research assistance of Marilee Corr.

${ }^{1}$ See, e.g., Interactive Gambling Act, 2001, pts. 2 \& 2A (Austl.) (prohibiting online gambling services to customers in Australia and other designated countries), available at http://parlinfoweb.aph.gov.au/piweb/Repository/Legis/oldBills/ Linked/31070101.pdf; Humphrey ex rel. State v. Granite Gate Resorts, Inc., 568 N.W.2d 715, 721 (Minn. Ct. App. 1997) (asserting personal jurisdiction over nonresident corporation and its principal for deceptive trade practices, false advertising, and consumer fraud in connection with an Internet gambling site); Vacco ex rel. People v. World Interactive Gaming Corp., 714 N.Y.S.2d 844, 851-54 (Sup. Ct. 1999) (enforcing state and federal laws to ban foreign corporation; its Antiguan subsidiary; and their principals, officers, and directors from operating or offering gambling over the Internet).

${ }^{2}$ See, e.g., 47 U.S.C. \$ 254(1) (1) (A) (ii) (2000) (requiring schools and libraries to adopt and implement policies to ensure "the safety and security of minors when using ... chat rooms"); NEV. REV. STAT. § 176A.413 (2001) (restricting ownership and use of online chat rooms by people previously convicted of cyber-stalking); Associated Press, China Tightens Internet Censorship, WASH. POST, Nov. 8, 2000, at A20 (reporting
} 
and seeking to enforce territorially based rules regarding trademarks, ${ }^{4}$ contractual relations, ${ }^{5}$ privacy norms, ${ }^{6}$ "indecent" content, ${ }^{7}$ and crime, ${ }^{8}$

Chinese restrictions requiring chat rooms to allow only officially approved topics to be discussed).

${ }^{3}$ See, e.g., IND. CODE $\$ \$ 26-2-8-101$ to -302 (2001) (containing the Uniform Electronic Transactions Act, which facilitates the use of online auction sites by giving legal effect to electronic signatures and contracts); N.C. GEN. STAT. $§ \S 66-311$ to -330 (2001) (same); T.G.I. Paris, Nov. 20, 2000 (enjoining Yahoo.com from permitting French users' access to Nazi memorabilia via Yahoo!'s auction sites), available at http://www. juriscom.net/txt/jurisfr/cti/tgiparis20001120.pdf. For further discussion of this case, see infra text accompanying notes $82-89$.

${ }^{4}$ See, e.g., Anticybersquatting Consumer Protection Act, Pub. L. No. 106-113, 113 Stat. 1501A-545 (1999) (codified as amended in scattered sections of 15, 16, and 28 U.S.C.) (providing for the "registration and protection of trademarks used in commerce"); Rachel Ross, China Demands Jurisdiction over Domain Names in Chinese, TORONTO STAR, Nov. 13, 2000 (reporting that China is seeking to ensure that it controls the distribution and administration of all Chinese-character domain names).

${ }^{5}$ See, e.g., Electronic Transactions Act 1999 (Austl.) (creating a regulatory regime intended to support and encourage business and consumer confidence in the use of electronic commerce), available at http://scaletext.law.gov.au/html/pasteact/3/3328/ top.htm; UNIF. COMPUTER INFO. TRANSACTIONS ACT, 7 U.L.A. 200 (2002) (providing a model uniform state law to govern online contracts), available at http://www.law. upenn.edu/bll/ulc/ucita/cita10st.doc.

${ }^{6}$ See, e.g., Electronic Communications Privacy Act, 18 U.S.C. § 2701(a) (1) (2000) (prohibiting unauthorized access to a "facility through which an electronic communication service is provided"); Data Protection Act, 1998, c. 29 (Eng.) (requiring technical and organizational measures against unauthorized or unlawful processing of personal data and against accidental loss of, destruction of, or damage to personal data), available at http://www.hmso.gov.uk/acts/acts1998/19980029.htm (July 24, 1998).

${ }^{7}$ See, e.g., 18 U.S.C. $\$ 2252$ A (2000) (prohibiting the receipt or distribution of sexually explicit photos of minors by any means, including by computer); Reno v. ACLU, 521 U.S. 844, 885 (1997) (striking down, on First Amendment grounds, provisions of the Communications Decency Act, 47 U.S.C. $\$ 223$ (Supp. II 1994), that criminalized certain content transmitted via online communication); ACLU v. Reno, 217 F.3d 162, 181 (3d Cir. 2000) (affirming, on First Amendment grounds, preliminary injunction preventing the enforcement of the Child Online Protection Act, 47 U.S.C. $\S$ 231 (Supp. IV 1998), which also criminalized certain content sent via online communication), vacated and remanded sub nom. by Ashcroft v. ACLU, 535 U.S. 564 (2002); Regina v. Pecciarich, [1995] O.R.3d 748 (holding that the distribution of child pornography by uploading photos to an electronic bulletin board was in violation of criminal statutes).

${ }^{8}$ E.g., Computer Fraud and Abuse Act, 18 U.S.C. $\$ 1030$ (2000) (applying federal law to newly discovered forms of computer abuse and providing civil remedies for certain types of computer crimes); Regulation of Investigatory Powers Act, 2000, c. 23 (Eng.) (defining criminal penalties for interception of traffic on all postal and telecommunications networks and any action that may cause the content of a message to become known to people other than the sender or intended recipient); Am. Online, Inc. v. LCGM, Inc., 46 F. Supp. 2d 444, 449-51 (E.D. Va. 1998) (holding that defendants who harvested e-mail addresses of AOL members using an extractor program and then used those addresses to send unauthorized bulk e-mail advertising their pornographic web sites were in violation of federal and state statutes). 
among others. These assertions of national authority have helped to reawaken scholarly interest in the classic triumvirate of topics historically grouped together under the rubric of conflict of laws: jurisdiction, choice of law, and recognition of judgments.

In a previous article, ${ }^{9}$ I argued that territorially-based conceptions of legal jurisdiction may no longer be adequate in an era when ideas of bounded nation-state communities operating within fixed territorial borders are under challenge. I offered instead what I called a cosmopolitan pluralist conception of jurisdiction: cosmopolitan because it recognized the possibility that people can hold multiple, sometimes nonterritorial, community affiliations; and pluralist because it acknowledged that forms of legal (or quasi-legal) jurisdiction can be asserted by communities beyond those represented by official statesanctioned courts.

This Essay turns the focus to choice of law and recognition of judgments. Analyzing three recent U.S. cases (two involving choice of law and one addressing recognition of judgments), I seek to apply some of the principles of cosmopolitanism to consider how courts should understand their institutional role in cases raising multinational concerns. (I leave to a future article the issue of how the insights of legal pluralism might inform conflict of laws.) The two choice-of-law cases, GlobalSantaFe Corp. v. Globalsantafe.com ${ }^{10}$ and Barcelona.com, Inc. v. Excelentisimo Ayuntamiento de Barcelona, ${ }^{11}$ both concerned the application of U.S. trademark law to transnational Internet domain name disputes. The third, Yahoo!, Inc. v. La Ligue Contre Le Racisme Et L'Antisémitisme, ${ }^{12}$ addressed whether or not a French judgment about Internet content accessible in France should be recognized by a U.S. court. Significantly, in each of the three cases, the judges failed even to conceive of the issues raised in conflicts terms. Instead, they simply assumed that U.S. law should apply, and though they included some bland statements about the importance of comity, there was no sustained discussion in any of the three decisions concerning how the choice of governing legal norms should be made. Thus, simply surfacing the way in which classic conflicts debates bear on these cases may itself be useful. In addition, I believe a cosmopoli-

\footnotetext{
${ }^{9}$ Paul Schiff Berman, The Globalization of Jurisdiction, 151 U. PA. L. REV. 311 (2002).

${ }^{10} 250$ F. Supp. 2 d 610 (E.D. Va. 2003).

11330 F.3d 617 (4th Cir. 2003).

12169 F. Supp. 2d 1181 (N.D. Cal. 2001), rev'd on other grounds, 379 F.3d 1120 (9th Cir. 2004), reh'g granted en banc, 399 F.3d 1010 (9th Cir. 2005).
} 
tan perspective might have altered the court's approach (if not always the result) in each case.

Taking seriously the observation that in conflicts scholarship there is truly nothing new under the sun, ${ }^{13}$ the cosmopolitan perspective I offer here does not purport to create a new theory of choice of law. Instead, it combines aspects of the Restatement (Third) of Foreign Relations Law, as well as the three major choice-of-law regimes of the twentieth century-vested rights, governmental interests, and the substantive law method-to shape an overall attitude with which judges can approach cases involving conflicting transnational legal norms. This attitude starts from the idea that governments have an interest not only in helping in-state litigants win the particular litigation at issue, but a more important longer-term interest in being cooperative members of an international system and sharing in its reciprocal benefits and burdens. Similarly, with regard to judgment recognition, the cosmopolitan perspective asks judges to consider the independent value of enforcing a foreign judgment, even when that judgment is contrary to local policy choices. Moreover, the cosmopolitan approach focuses less on literal contacts with a territorially-based sovereign entity and more on the extent to which the various parties might be deemed to have affiliations with the possible communities seeking to impose their norms. Thus, while derived from various extant conflicts theories, the cosmopolitan perspective yields a distinctive approach, and one that I believe is better suited to a world of interconnection, interrelationship, and multiple community affiliations.

My discussion proceeds in four parts. First, I describe the three cases, noting the ways in which each of the U.S. courts involved managed to discount the possibility of deferring to the actions of foreign courts. Second, I briefly summarize the major twentieth-century choice-of-law approaches and suggest a perspective that blends aspects of all three (as well as the Third Restatement of Foreign Relations Law), while also drawing on insights from the voluminous interdisciplinary literature on cosmopolitanism. Third, I argue that in recognition of judgments, as in choice of law, deference to foreign court judgments might sometimes be an independent value, and I suggest that some of the principles that govern the recognition of judgments in the domestic U.S. context might therefore also apply transnationally. Finally, I return to the cases and discuss how the cosmopolitan perspective on

${ }^{13}$ See, e.g., Friedrich K. JUenger, Choice of LAW AND Multistate Justice (1993) (arguing that each of the major twentieth-century conflicts theories had already been propounded at some earlier point in history). 
choice of law and judgment recognition described in the previous sections might have affected the courts' analyses. ${ }^{14}$ In conclusion, I suggest an ongoing research agenda for further refining and developing a more comprehensive cosmopolitan approach. Certainly, as these cases make clear, reconceptualizing the principles underlying courtto-court relations is essential in a world where the idea of a transnational community of courts is fast becoming one of the dominant realities of twenty-first century law. ${ }^{15}$

\section{A PAROChial Vision OF CONFlict Of LAWS: THREe CASE STUdIES}

The three cases described in this section all take the view, explicitly or implicitly, that U.S. law must be applied to the transnational dispute at issue. That, in and of itself, is not necessarily cause for concern, but it is striking that these courts do not even engage in traditional conflicts analysis to reach their conclusions. Instead, simply because U.S. law may apply, the judges seem to assume that U.S. law should apply, even without any sustained discussion of other possible outcomes. At most, there is some consideration of comity. But comity is a weak analytical framework because it comes into play only as a discretionary restraining factor after the courts have already decided that U.S. law applies. Comity analysis, therefore, is not sufficient to replace a serious inquiry concerning the principles needed to determine which legal rules should govern in the first place.

\section{A. Choice of Law}

\section{GlobalSantaFe Corp. v. Globalsantafe.com}

Historically, the boundaries of trademark law have been delineated in part by reference to physical geography. ${ }^{16}$ Thus, if I own a store in New York City called "Berman's," I will not, as a general mat-

\footnotetext{
${ }^{14}$ Significantly, although one might ultimately agree with the final outcome in any or all of these cases, the mode of analysis remains suspect.

${ }^{15}$ See, e.g., Jenny S. Martinez, Towards an International Judicial System, 56 STAN. L. REV. 429, 432 (2003) ("[I]n a world of global commerce and communications, national courts cannot avoid interactions with the larger world, and lawyers and scholars cannot ignore the transnational aspects of modern litigation.").

${ }^{16}$ See Graeme B. Dinwoodie, Trademarks and Territory: Detaching Trademark Law from the Nation-State, 41 Hous. L. REV. 885, 887 (2004) (" $[\mathrm{I}] \mathrm{t}$ is an axiomatic principle of domestic and international trademark law that trademarks and trademark law are territorial.").
} 
ter, be able to prevent a person in Australia from opening a store that is also called "Berman's," even if I have previously established a trademark in my name. The idea is that customers would be unlikely to confuse the two stores because they are in markets that are spatially distinct. ${ }^{17}$ In the online world such clear spatial boundaries are collapsed because, as the domain name system is currently organized, there can be only one bermans.com domain name, and it can only point to one "location."

In the early to mid-1990s, as corporations and entrepreneurs began to understand the potential value of a recognizable domain name, pressure increased to create trademark rights in such names. In response, Congress first passed the Federal Trademark Dilution Act ${ }^{19}$ and then the Anticybersquatting Consumer Protection Act (ACPA), which provides an explicit federal remedy to combat so-called "cybersquatting." ${ }^{20}$ According to the congressional reports, the ACPA is meant to address cases where non-trademark holders register wellknown trademarks as domain names and then try to "ransom" the names back to the trademark owners. ${ }^{21}$

Nevertheless, even if one believes that reining in "cybersquatters" is a laudable goal (and that goal itself has been questioned), ${ }^{22}$ there

${ }^{17}$ See Hanover Milling Co. v. Metcalf, 240 U.S. 403, 415 (1916) (“[W]here two parties independently are employing the same mark upon goods of the same class, but in separate markets wholly remote the one from the other, the question of prior appropriation is legally insignificant ... [except in cases of bad faith]."). This is not an absolute rule, of course, because "famous or well-known marks may well leap oceans and rivers, cross national borders, and span language barriers to achieve international recognition.” Dan L. Burk, Trademark Doctrines for Global Electronic Commerce, 49 S.C. L. REV. 695, 720 (1998). See also Vaudable v. Montmartre, Inc., 193 N.Y.S.2d 332, 332 (Sup. Ct. 1959) (enjoining the use by a restaurant in New York of the name and decor of Maxim's Restaurant in Paris). Nevertheless, the likelihood-of-confusion standard historically has tended to imbed a geographical limitation.

${ }^{18}$ Of course, users going to www.bermans.com could be shown an introductory screen that provides a choice of which Berman's site they wish to access.

${ }^{19}$ Federal Trademark Dilution Act of 1995, Pub. L. No. 104-98, 109 Stat. 985 (codified at 15 U.S.C. $\S \S 1125,1127$ (Supp. 1996)).

${ }^{20}$ Anticybersquatting Consumer Protection Act, Pub. L. No. 106-113, § 3002, 113 Stat. 1501A-545, 1501A-545 (1999) (codified at 15 U.S.C. $\$ 1125$ (d) (2000)); see H.R. REP. No. 106-412 (1999) (detailing the Act).

${ }^{21}$ See H.R. REP. NO. 106-412, at 5-7 (1999) (noting that "[s] ometimes these pirates put pornographic materials on theses sights [sic] in an effort to increase the likelihood of collecting ransom by damaging the integrity of a [trade]mark"); S. REP. NO. 106140, at 4-7 (1999) (highlighting testimony regarding attempts to ransom domain names to the highest bidder).

${ }^{22}$ For example, Yochai Benkler has argued that the strong protection of trademarks in domain names has "maintain [ed] the value of brand names at the expense of 
can be little doubt that the application of trademark law to domain names has meant that trademark law has become unmoored to physical geography and is now more likely to operate extraterritorially. Potentially, even those who are legitimately using a website that happens to bear the name of a famous mark held by an entity across the globe could be forced to relinquish the name. ${ }^{23}$ In addition, this unmooring

the efficiency of electronic commerce." Yochai Benkler, Net Regulation: Taking Stock and Looking Forward, 71 U. COLO. L. REv. 1203, 1256 (2000). According to Benkler, the current approach assumes that consumers will, for the foreseeable future, seek out websites primarily by typing into their browser a uniform resource locator (URL) such as http://www.brandname.com, rather than by using search engines or product review sites. This assumption is then employed to justify permitting the owner of the trademark in a brand name to control use of that brand name in a URL. Id. at 1256-57. Such a legal determination, however, does not just assume a static model for the digital environment where customer habits, browser configurations, and search engines will continue as they are, but also enforces such a static model backed by the power of law. Id. at 1257. As Benkler points out:

The private stakes for those corporations who have invested in building brand recognition and plan to recoup their investments by exercising some price discipline using the value of their brand name as a search-cost saving device for consumers are obvious. The public benefits of protecting these costs by encouraging consumers not to take advantage of the reduced search costs in the electronic commerce environment are more questionable.

Id. He suggests that we might instead "accept the declining importance of trademarks [in the digital environment, ] . . limit legal protection to situations where competitors try to use a mark to confuse consumers, and . . abandon the notion of dilution as protection of goodwill, which developed to protect the famous marks most useful in the old environment." Id. at 1249; cf. Manchester Airport PLC v. Club Club Ltd., Case No. D2000-0638, World Intellectual Property Org. [WIPO] Arbitration and Mediation Ctr. Admin. Panel Decision (Aug. 22, 2000), at http://www.arbiter.wipo.int/domains/ decisions $/ \mathrm{html} / 2000 / \mathrm{d} 2000-0638 . \mathrm{html}$ (stating that respondent attempted to sell the domain name to the complainant "for an amount well in excess of the registration fees," but noting that "selling a domain name is not per se prohibited by the ICANN [Internet Corporation for Assigned Names and Numbers] Policy (nor is it illegal or even, in a capitalist system, ethically reprehensible)").

${ }^{23}$ In response to this problem, the World Intellectual Property Organization and the Assembly of the Paris Union for the Protection of Industrial Property adopted, in the fall of 2001, a Joint Recommendation calling for a definition of "use" for purposes of trademark law that would protect legitimate users of marks who disclaimed any intent to engage in commerce in a particular country. Joint Recommendation Concerning Provisions on the Protection of Marks, and Other Industrial Property Rights in Signs on the Internet art. 2 (2001), at http://www.wipo.int/about-ip/en/ development_iplaw/doc/pub845.doc. The ACPA at first glance seems to limit its extraterritorial scope in a similar way because it extends in rem jurisdiction only if the domain name violates rights protected by the Lanham Act, 15 U.S.C. $§ 1125$ (d)(1) (a), which in turn requires that a mark be used "in commerce." See Dinwoodie, supra note 16, at 909. See also id. at 909 n.85 (explaining that this requirement has been widely accepted by judges despite the lack of an explicit statutory basis). Presumably this "use in commerce" requirement means that the mark must actually be used in the U.S. market to give rise to a cause of action. However, because a website located abroad 
of trademarks from territory creates the possibility that individual countries will interpret their trademark laws expansively, thereby reducing trademark rights "to their most destructive form": the mutual ability to block (or at least interfere with) the online use of marks recognized in other countries. ${ }^{24}$ Moreover, each of the parties claiming ownership in a trademark could sue in a different country, and, because of differences in substantive law, each party could win. ${ }^{25}$

This is the backdrop for GlobalSantaFe Corp. $v$. Globalsantafe.com. ${ }^{26}$ On September 3, 2001, Global Marine, Inc. and Santa Fe International Corporation announced their agreement to merge into an entity to be known as GlobalSantaFe Corporation. ${ }^{27}$ Less than a day later, Jongsun Park, a citizen of South Korea, registered the domain name globalsantafe.com with the Korean domain name registrar Hangang. ${ }^{28}$ In response, Global Marine and Santa Fe filed an in rem action in the Eastern District of Virginia under the ACPA. ${ }^{29}$ The ACPA provides in rem jurisdiction over a domain name wherever that name is registered. ${ }^{30}$ Thus, for example, if people register domain

may render services to customers in the United States, it is unclear whether the "use in commerce" requirement will in practice provide much of a limitation on the potentially extraterritorial application of the in rem provisions. See, e.g., International Bancorp, LLG v. Société des Bains de Mer, 329 F.3d 359, 364 (4th Cir. 2003) (ruling that providing services abroad to U.S. customers can constitute "use in commerce" for purposes of the Act). For a discussion of this case, see Dinwoodie, supra note 16, at 91419.

${ }^{24}$ See Graeme B. Dinwoodie, Private International Aspects of the Protection of Trademarks 27, Presented at the WIPO Forum on Private International Law and Intellectual Property (Jan. 30-31, 2001) (WIPO Doc. No. WIPO/PIL/01/4 2001) (noting that " $[\mathrm{t}]$ his 'mutual blocking' capacity is neither efficient nor a positive contribution to the globalization of markets or the development of ecommerce"), available at http:// www.wipo.org/pil-forum/en/documents/doc/pil_01_4.doc. Catherine T. Struve and R. Polk Wagner have also raised the specter that realspace sovereigns may increasingly attempt to segment the domain system itself, to insure that any trademark action involving domain names will have the requisite territorial nexus to support the assertion of jurisdiction. Catherine T. Struve \& R. Polk Wagner, Realspace Sovereigns in Cyberspace: Problems with the Anticybersquatting Consumer Protection Act, 17 BERKELEY TECH. L.J. 989, 1031-34 (2002). As Struve and Wagner point out, such territorially based segmentation of the domain name system would result in "the dramatic reduction in utility provided by the system itself." Id. at 1031 .

${ }^{25}$ See, e.g., Mecklermedia Corp. v. D.C. Cong. GmbH, 1998 Ch. 40, 53 (Eng.) (noting that the cause of action for using trademarked language is different in Germany and England and, thus, simultaneous proceedings could continue).

2625 F. Supp. 2d 610 (E.D. Va. 2003).

${ }^{27} I d$. at 613 .

${ }^{28} \mathrm{Id}$.

${ }^{29} I d$.

${ }^{30} 15$ U.S.C. $\$ 1125(\mathrm{~d})(2)(\mathrm{C})$ (2000) ("In an in rem action ... a domain name 
names online via a website owned by Network Solutions, a domain

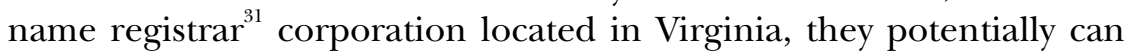
be forced, under the ACPA, to defend a trademark action in Virginia whether or not they have ever set foot in Virginia or knew Network Solutions was a Virginia corporation.

In this case, however, jurisdiction was further complicated by the fact that Park had not even registered the domain name with a U.S. registrar, but with a South Korean one. Nevertheless, the ACPA also authorizes in rem jurisdiction in the judicial district where the overall domain name registry is located. ${ }^{32}$ Based on this provision, the district court determined that it could exercise jurisdiction because VeriSign, which administers the entire ".com" registry, is located in Virginia." And, having determined that the substantive provisions of the ACPA had been met, the court therefore ordered both Hangang and VeriSign to "take all appropriate steps to transfer the domain name" to GlobalSantaFe. ${ }^{34}$

Approximately a week later, Park filed an application for an injunction in the District Court of Seoul, South Korea, seeking an order preventing Hangang from transferring the domain name. ${ }^{35}$ Ruling that the Virginia court did not have proper jurisdiction, the Korean court provisionally granted the injunction, and Hangang, presumably responding to the Korean court's injunction, subsequently refused to transfer the domain name. ${ }^{36}$ In an effort to resolve this transnational stalemate, GlobalSantaFe returned to the court in Virginia seeking an

shall be deemed to have its situs in the judicial district in which ... the domain name registrar, registry, or other domain name authority that registered or assigned the domain name is located ....").

${ }^{31}$ A registrar is one of several entities for a given top-level domain (such as .com, .edu, .gov, .uk, etc.) that is authorized by the Internet Corporation for Assigned Names and Numbers to grant registration of domain names. DAVID BENDER, COMPUTER LAW $\S 3 \mathrm{D} .05[3]$, at 3D-104 (2002).

${ }^{32}$ See supra note 30 . For each top-level domain (such as .com, .gov, .edu, .uk, etc.), a single registry company is responsible for keeping the records and a directory of all the domain names within that domain. When an individual or corporation company wants the rights to a new domain name, it contacts a registrar. The registrar submits the domain name to the registry, which enters the assigned domain name into a database. Currently, VeriSign Global Registry Services is the sole registry for ".com" domain names.

${ }^{33}$ GlobalSantaFe, 250 F. Supp. 2d at 614-15.

${ }^{34} I d$. at 614 .

${ }^{35} I d$.

${ }^{36} I d$. 
additional order directing VeriSign to cancel the infringing domain name from the ".com" registry. ${ }^{37}$

The District Court reaffirmed that it had proper in rem jurisdiction over the case pursuant to the ACPA because VeriSign is located in Virginia. ${ }^{38}$ The court also reiterated that Park had violated the substantive provisions of the ACPA. ${ }^{39}$ And, after a lengthy discussion of the mechanics concerning how a registry company would effectively cancel or transfer a domain name, ${ }^{40}$ the court concluded that such a remedy was both available under the ACPA and appropriate given the unwillingness of Hangang to act in violation of the Korean court's order. $^{41}$

From a conflicts perspective, what is most striking about the decision is that the court focuses almost exclusively on its jurisdiction to hear the case, but never questions that the ACPA is the only possibly relevant legal regime. Indeed, the court seems to assume that the ACPA's legal reach is limited solely by the scope of the court's jurisdiction, not by any choice-of-law considerations. Thus, in the court's view, the only significant gap in the ACPA's trademark enforcement regime is for domain names registered under top-level domains whose registry is located outside the United States. Never does it seem to occur to the court that, even if it had jurisdiction over the action, it might nevertheless choose South Korean (or some other) law as providing the operative legal norms for resolving the dispute.

This single-minded focus on jurisdiction (and therefore the physical location of registry companies) poses potential problems for ACPA enforcement in the future. As the court recognizes, if jurisdiction is all, then the ACPA can only provide a broad-based remedy in domain name trademark cases so long as the registries of the most popular top-level domains remain in the United States. ${ }^{42}$ Thus, if country-code top-level domains were to become more popular, or if the registries for generic domains such as ".com" and ".net" were relocated outside the physical territory of the United States, then U.S. trademark rights in domain names would face serious enforcement challenges. ${ }^{43}$ Such

37 Id.

${ }^{38} I d$. at 614-15.

${ }^{39} I d$. at $615-16$.

Id. at $617-24$.

${ }^{41} I d$. at 623.

${ }^{42} I d$.

${ }^{43}$ See Struve \& Wagner, supra note 24, at 1019-41 (warning that aggressive assertion of U.S. jurisdiction over the domain name system may ultimately lead to the sys- 
difficulties are a natural consequence of laws that are deemed to apply to the full extent of their territorially-based jurisdictional reach. But, of course, as choice-of-law scholars have long recognized, laws need not be applied to the full extent of their jurisdictional reach, and concerns about the establishment of competing or conflicting trademark systems on the Internet are precisely the sorts of concerns that might animate a more restrained application of forum law.

In any event, having concluded that the case was within its jurisdiction and that, therefore, U.S. law necessarily applied, the court only at the very end of its opinion asked whether "concerns of international comity" might dictate deference to the injunction issued by the Korean court. $^{44}$ Even here, however, the court did not ask about the content of South Korean trademark law; it only asked whether deference was owed to the court decision granting the actual injunction. ${ }^{45}$ Having framed the issue in this way, the court resolved it by reference to a principle that in rem cases should generally be decided by the first court to exercise jurisdiction over the property in question. ${ }^{46}$ And, since the original Virginia court order preceded the Korean court injunction, the Virginia court found deference inappropriate. ${ }^{47}$

The vision of choice of law that emerges from the decision, therefore, is founded solely on jurisdictional power and a race to the courthouse. A state can enact legal norms with extremely broad extraterritorial reach, and courts within that state are bound to apply those norms to a multinational dispute so long as the case was commenced there first. Needless to say, this is not a particularly thoughtful or nuanced choice-of-law regime, nor does it take into account the possible long-term benefits that might accrue from adopting a more restrained application of forum law or from considering the forum's own interest in harmonious international adjudicatory processes.

\section{Barcelona.com, Inc. v. Excelentisimo Ayuntamiento de Barcelona}

Whereas the choice-of-law issues in GlobalSantaFe were made more complicated by the fact that the parties were from different countries, in Barcelona.com, all of the principal actors in the dispute were from

\footnotetext{
tem's segmentation because other countries could establish competing systems for registries maintained outside of the United States).

${ }^{44}$ GlobalSantaFe, 250 F. Supp. 2d at 624.

${ }^{45} I d$.

${ }^{46}$ See id. at 624-26 (referring to the first-in-time rule known as the Princess Lida doctrine)

${ }^{47}$ Id. at 625 .
} 
Spain. ${ }^{48}$ Yet even here the Fourth Circuit, reversing a contrary ruling of the district court, ${ }^{49}$ eschewed Spanish law and insisted on applying the ACPA. ${ }^{50}$ Moreover, this decision was again reached without significant consideration of choice-of-law issues.

The case involved the right to the domain name barcelona.com. In 1996, Mr. Joan Nogueras Cobo ("Nogueras"), a Spanish citizen, registered barcelona.com with the Virginia-based domain name registrar, Network Solutions. ${ }^{51}$ Subsequently, Nogueras formed a corporation under U.S. law, called Bcom, Inc. ${ }^{52}$ Despite the U.S. incorporation, however, the company had no offices, employees, or even a telephone listing in the United States. ${ }^{53}$ Nogueras (and the Bcom servers) remained in Spain. ${ }^{54}$

The Barcelona City Council asserted that Nogueras had no right to use barcelona.com under Spanish trademark law and demanded that he transfer the domain name registration to the City Council. ${ }^{55}$ When Nogueras refused, the City Council filed a complaint with the World Intellectual Property Organization (WIPO). ${ }^{56}$ Several months later, the WIPO panelist ruled in favor of the City Council. ${ }^{57}$ Instead of transferring the domain name, however, Bcom filed suit in federal

${ }^{48}$ Barcelona.com, Inc. v. Excelentisimo Ayuntamiento de Barcelona, 330 F.3d 617 (4th Cir. 2003).

${ }^{49}$ Barcelona.com, Inc. v. Excelentisimo Ayuntamiento de Barcelona, 189 F. Supp. 2d 367 (E.D. Va. 2002).

${ }^{50}$ Barcelona.com, 330 F.3d at 630 . To be sure, because the claim at issue sought only a declaratory judgment as to the plaintiff's rights under the Lanham Act, it is possible to construe the Fourth Circuit decision as merely clarifying U.S. law without requiring that this law be the ultimate rule of decision in the case. However, nowhere does the court state that it is rendering such a limited ruling, and instead explicitly reverses the district court's application of Spanish law and remands so that the district court can "grant the appropriate relief under [the Lanham Act]." Id. at 630. In addition, the appellate opinion states that the ACPA can be used specifically to reverse arbitration decisions "grounded on principles foreign or hostile to American law." Id. at 626. Both of these statements strongly imply that the Fourth Circuit considered its application of U.S. law to be dispositive.

${ }^{51} I d$. at 620 .

${ }^{52} I d$.

${ }^{53} \mathrm{Id}$.

${ }^{54} \mathrm{Id}$.

${ }^{55} \mathrm{Id}$.

${ }^{56} I d$. at 621 . Every domain name issued by Network Solutions is issued under a contract, the terms of which include a provision requiring resolution of disputes through the Uniform Dispute Resolution Policy (UDRP) promulgated by the Internet Corporation for Assigned Names and Numbers. Id. The WIPO complaint was filed in accordance with the terms of the UDRP. Id.

${ }^{57}$ Id. 
court, again in Virginia, seeking a declaratory judgment that the registration of barcelona.com was not unlawful. ${ }^{58}$

The district court, after deciding that the WIPO administrative proceedings would be given "no weight," the ACPA, first considering whether either party possessed a valid trademark for the name "Barcelona." Significantly, the district court sought to answer this question by reference to both U.S. and Spanish law. ${ }^{60}$ And, although the court concluded that neither party possessed a U.S. trademark in the name "Barcelona," it did find that the City Council possessed multiple Spanish trademarks containing the term "Barcelona," such as "Barcelona Teatre," "Barcelona Canal," and "Barcelona Television." ${ }^{61}$ The court also noted that, under Spanish law, if a trademark consists of two or more words, the operative issue is which word creates the dominant impression in the mind of the consumer. Here, that word is obviously "Barcelona." ${ }^{62}$ Finally, the court determined that, under Spanish law, the names of communities, municipalities, and provinces cannot be registered as trademarks without authorization by municipal officials, and neither Nogueras nor Bcom had received such authorization. ${ }^{63}$ Thus, the court ruled that the City Council possessed a "legally valid Spanish trademark" for the word "Barcelona." "The district court then turned to the other elements of the ACPA, finding both likelihood of consumer confusion and the requisite bad faith intent to profit from the domain name registration. ${ }^{65}$ Accordingly, the district court ruled in favor of the City Council and refused to issue the declaratory judgment Bcom had sought. ${ }^{66}$

The Fourth Circuit reversed. ${ }^{67}$ Significantly, the major issue on which the appellate court disagreed with the trial court was the use of Spanish law to determine whether the City Council had a valid trademark. Citing Section 1114(2)(D) (v) of the ACPA, the Fourth Circuit

$58 I d$.

59 Barcelona.com, 189 F. Supp. 2d at 371.

${ }^{60}$ Id. at 371-72.

61 Id. at 371-72, 372 n.3.

${ }^{62}$ Id. at 372

${ }^{63} \mathrm{Id}$.

${ }^{64} I d$.

${ }^{65} I d$. at $372-73$.

${ }^{66} I d$. at 373. The court also ruled in favor of the City Council on an ACPA counterclaim against Nogueras, finding that Nogueras had engaged in bad faith intent to profit from the City Council's valid trademark. Id. at 372-77.

${ }^{67}$ Barcelona.com, Inc. v. Excelentisimo Ayuntamiento de Barcelona, 330 F.3d 617, 619-20, 629 (4th Cir. 2003). 
emphasized that the principal issue to be decided is whether "plaintiff's registration or use of the domain name is not unlawful under the Lanham Act." ${ }^{\prime 68}$ According to the appellate panel, this language makes clear that only U.S. law may be used to determine the existence of a valid trademark or its possible infringement. ${ }^{69}$ Having decided to apply U.S. trademark law, the court then concluded that "Barcelona" is "a purely descriptive geographical term entitled to no trademark protection" under the ACPA. ${ }^{70}$ Accordingly, the court found nothing unlawful in Nogueras' registration of barcelona.com and therefore reversed the district court's ruling. ${ }^{71}$

Thus, the Fourth Circuit, like the court in GlobalSantaFe, applied U.S. law to an international trademark dispute, invoking principles of territoriality. Despite the fact that the principal actors in the dispute were all in Spain, the appellate court opined that the ACPA, "[b]y requiring application of United States trademark law to this action brought in a United States court by a United States corporation involving a domain name administered by a United States registrar" was consistent with "the fundamental doctrine of territoriality upon which our trademark law is presently based."

This doctrine of territoriality likely derives from the 1883 Paris Convention for the Protection of Industrial Property ${ }^{73}$ (upon which the Fourth Circuit relied ${ }^{74}$ ). Indeed, the concern animating the Convention was that absent a doctrine of territoriality, a country could create a "world mark" simply by granting a trademark under its local law, thereby preventing anyone, anywhere in the world, from using that name. ${ }^{75}$ Such an extraterritorial encroachment was unacceptable in an era when it was presumed that trademarks could easily operate locally because the use of a trade name in one country would have no

${ }^{68} I d$. at 626 (emphasis added).

${ }^{69} I d$. at $627-28$.

${ }^{70} I d$. at $629-30$.

${ }^{71} I d$. at 630 . The Fourth Circuit also vacated the district court's decision concerning the City Council's counterclaim (without reaching the merits) because the appellate panel concluded that no counterclaim had actually been filed. Id.

${ }^{72} I d$. at 628.

${ }^{73}$ Paris Convention for the Protection of Industrial Property, Mar. 20 1883, art. 10bis, as last revised at Stockholm, Jul. 14, 1967, 21 U.S.T. 1583, 828 U.N.T.S. 305.

${ }^{74}$ Barcelona.com, 330 F.3d at 628.

${ }^{75}$ See, e.g., Tortsten Bettinger \& Dorothee Thum, Territorial Trademark Rights in the Global Village-International Jurisdiction, Choice of Law and Substantive Law for Trademark Disputes on the Internet (Part Two), 31 InT'L Rev. OF InTELl. Prop. \& Competition L. 285, 286 (2000) (explaining the basis of the doctrine of territoriality with regard to trademarks). 
significant impact on the use of the same name by a different entity in another country.

When considering trademarks in domain names, however, a single-minded emphasis on territoriality may itself create law with substantial extraterritorial effects. For example, by applying the ACPA in GlobalSantaFe, the U.S. district court necessarily imposed U.S. trademark law on a South Korean domain name registrant and a South Korean domain name registrar, even though neither had any significant contact with the United States. Likewise, in Barcelona.com, the Fourth Circuit applied U.S. trademark law to a dispute where all the principal actors were Spanish and where the issue concerned a domain name associated with the name of a major city in Spain. Both of these cases demonstrate that, by applying a rigid conception of territoriality to international trademark disputes (at least in the context of domain names), courts run the risk of imposing U.S. law extraterritorially and creating precisely the sort of world mark that the principle of territoriality was originally designed to avoid.

Indeed, as Graeme Dinwoodie has made clear, courts have used the territoriality principle to avoid the need either to reconcile conflicting trademark claims or to articulate standards for determining the appropriate prescriptive law to apply. ${ }^{76}$ Instead, courts "simply recognize forum-determined rights and apply forum law or, alternatively, dismiss the case if it does not implicate such rights or laws.",77 But in an era of global commercial activity, "where consumer understanding, product markets, and producer marketing[] disdain territorialism, the value of such a rule as the lodestar for international trademark law becomes questionable." ${ }^{, 7}$ And, of course, the Internet renders such territorialism both impractical (because of the difficulty of locating a relevant transaction ${ }^{79}$ ) and unwise (because, as discussed above, strict territorialism will actually result in extraterritorial encroachment on the trademark laws of other countries). In addition, "fictionally localizing an activity that is inherently non-local ... de-

${ }^{76}$ See Dinwoodie, supra note 24 , at 31

${ }^{77} \mathrm{Id}$.

${ }^{78} \mathrm{Id}$.

${ }^{79}$ See, e.g., Am. Bar Ass'n, Cyberspace Jurisdiction Project, Achieving Legal and Business Order in Cyberspace: A Report on Global Jurisdiction Issues Created by the Internet, reprinted in 55 Bus. LAW. 1801, 1826 (2000) ("[I]f an activity occurs in Cyberspace, it is impossible to ascribe it to any specific physical space."). Although somewhat exaggerated as a general matter, this statement is relatively accurate when considering the "location" of a domain name. 
taches the applicable law from social reality, which undermines its legitimacy." $"$

Accordingly, we need to reconsider the traditional assumption that trademark disputes must always be resolved by applying the law of the forum country. Instead, cases involving international actors require courts to use choice-of-law principles in order to determine the appropriate legal norms. Moreover, such cases may help suggest choice-of-law frameworks that take proper account of the actual community affiliations of the parties, as well as the interests nation-states have in being a functioning part of an interlocking international network of domestic trademark regimes.

\section{B. Recognition of Judgments}

\section{Yahoo! Inc. v. La Ligue Contre Le Racisme Et L'Antisémitisme}

As with choice of law, the doctrine of recognition of judgments encourages courts to consider the multistate nature of the legal issue they are addressing, rather than simply assuming that the question must be resolved through the application of forum law. While such a doctrine is obviously a stronger command in the U.S. domestic context, where the Constitution's Full Faith and Credit Clause applies, ${ }^{81}$ the principles underlying the recognition of judgments could also inform court decisions concerning international judgment recognition.

Again, as with trademark choice-of-law issues, the rise of the Internet makes it likely that such international recognition of judgments cases will arise with greater frequency. Cyberspace creates the possibility (and perhaps even the likelihood) that content posted online by a person in one physical location will violate the law in some other physical location. In such circumstances, there is an inevitable problem of extraterritoriality. Will the person who posts the content be required to conform her activities to the norms of the most restrictive community of readers? Or, alternatively, will the community of readers, which has adopted a norm regarding Internet content, be subjected to the proscribed material regardless of its wishes? The answers to these questions depend both on whether the community of

\footnotetext{
${ }^{80}$ Dinwoodie, supra note 24 , at 32.

${ }^{81}$ See U.S. CONST. art. IV, § 1 ("Full Faith and Credit shall be given in each State to the public Acts, Records, and judicial Proceedings of every other State. And the Congress may by general Laws prescribe the Manner in which such Acts, Records and Proceedings shall be proved, and the Effect thereof.").
} 
readers asserts the jurisdictional authority to impose its norms on the foreign content provider and whether the home country of the content provider chooses to recognize the norms imposed.

The celebrated case involving Yahoo!'s content in France raises such issues. On May 22, 2000, the Tribunal de Grande Instance de Paris issued a preliminary injunction against Yahoo.com, ordering the site to take all possible measures to dissuade and prevent access in France to Yahoo! auction sites that sell Nazi memorabilia or other items that are sympathetic to Nazism or constitute Holocaust denial. ${ }^{82}$ Undisputedly, selling such merchandise in France would violate French law, ${ }^{83}$ and Yahoo.fr, Yahoo!'s French subsidiary, complied with requests that access to such sites be blocked. ${ }^{84}$ What made this action noteworthy was that the suit was brought not only against Yahoo.fr, but against Yahoo.com, an American corporation, and the court sought to enjoin access to non-French websites stored on Yahoo!'s non-French servers.

Of course, one can easily see why the court and the complainants in this action would have taken this additional step. Shutting down access to web pages on Yahoo.fr does no good at all if French citizens can, with the click of a mouse, simply go to Yahoo.com and access those same pages. On the other hand, Yahoo! argued that the French assertion of jurisdiction was impermissibly extraterritorial in scope. ${ }^{85}$ According to Yahoo!, in order to comply with the injunction it would need to remove the pages from its servers altogether (not just for the French audience), thereby denying such material to non-French citizens, many of whom have the right to access the materials under the

${ }^{82}$ T.G.I. Paris, May 22, 2000, available at http://www.juriscom.net/txt/jurisfr/cti/ tgiparis20000522.htm. It is worth noting that the proper translation of the French order is a matter of some dispute. See Patricia L. Bellia, Paul Schiff Berman \& David G. Post, Cyberlaw: Problems of Policy and JuRisPrudence in the INFORMation AGE 174 (2d ed. 2003) (discussing the translation issue). The paraphrase I use (which strikes me as the most accurate) derives from Joel R. Reidenberg, Yahoo and Democracy on the Internet, 42 JURIMETRICS 261, 262 (2002). An example of the type of auction page at issue can be found at http://www.legalis.net/jnet/illustration/yahoo_auctions. htm.

${ }^{83}$ See Code PÉnAl [C. PÉN], art. R.645-1 (prohibiting the public display of Nazi memorabilia except for the purposes of an historical film, show, or exhibit), available at http://www.legifrance.gouv.fr/WAspad/RechercheSimpleCode?commun=CPENAL\&c ode $=\mathrm{r} 645-1$.

${ }^{84}$ See T.G.I. Paris, Nov. 20, 2000 (noting that Yahoo! France had posted warnings on its site that the user could access revisionist sites through Yahoo! U.S., and that the visiting of such sites is prohibited and punishable by French law), available at http:// www.juriscom.net/txt/jurisfr/cti/tgiparis20001120.pdf.

${ }^{85} I d$. 
laws of their countries. ${ }^{86}$ Most importantly, Yahoo! argued that such extraterritorial censoring of American web content would run afoul of the First Amendment of the U.S. Constitution. ${ }^{87}$ Thus, Yahoo! and others ${ }^{88}$ contended that the French assertion of jurisdiction was an impermissible attempt by France to impose global rules for Internet expression. $^{89}$

Yet, as in the trademark cases, the extraterritoriality charge runs in both directions. If France is not able to block the access of French citizens to proscribed material, then the United States will effectively be imposing First Amendment norms on the entire world. And though geographical tracking software might seem to solve the problem by allowing websites to offer different content to different users, such a solution is probably illusory because it would still require the sites to analyze the laws of all jurisdictions to determine what material to filter for which users. ${ }^{90}$

In the end, rather than filter out French users, Yahoo! chose a two-pronged strategy. First, it decided to remove the auction sites from its servers altogether, but it claimed that such a decision was "voluntary" and unrelated to the French court ruling. ${ }^{91}$ Second, it filed suit in United States District Court in the Northern District of

${ }^{86} I d$.

${ }^{87}$ Id.

88 See, e.g., Carl S. Kaplan, Experts See Online Speech Case as Bellwether, N.Y. TIMES ON THE WEB, Jan. 5, 2001, at http://www.nytimes.com/2001/01/05/technology/ 05CYBERLAW.html (quoting the warning of Barry Steinhardt, associate director of the American Civil Liberties Union, that if "litigants and governments in other countries ... go after American service providers ... we could easily wind up with a lowest common denominator standard for protected speech on the Net").

89 As Greg Wrenn, associate general counsel for Yahoo!'s international division, put it: "We are not going to acquiesce in the notion that foreign countries have unlimited jurisdiction to regulate the content of U.S.-based sites." Id.

${ }^{90}$ Indeed, one member of an expert panel appointed by the Yahoo! court to explore the feasibility of geographical filtering subsequently argued that such filtering, though technically feasible, would impose a tremendous burden on services such as Yahoo! because such services would be required "to maintain a huge matrix of pages versus jurisdictions to see who can and can't see what." Ben Laurie, An Expert's Apology (Nov. 21, 2000), available at http://www.apache-ssl.org/apology.html.

91 See Press Release, Yahoo!, Yahoo! Enhances Commerce Sites for Higher Quality Online Experience (Jan. 2, 2001) (announcing new product guidelines for its auction sites that prohibit "items that are associated with groups which promote or glorify hatred and violence"), available at http://docs.yahoo.com/docs/pr/release675.html. But cf. Troy Wolverton \& Jeff Pelline, Yahoo to Charge Auction Fees, Ban Hate Materials, CNET NEWS.COM, Jan. 2, 2001, at http://news.cnet.com/news/0-1007-200-4352889.html (noting that Yahoo!'s new policy regarding hate-related materials followed action by the French court). 
California, seeking a declaratory judgment that the French court's orders were not enforceable in the United States pursuant to the First Amendment. ${ }^{92}$

Faced with the question of whether or not to enforce the French court's order, the district court started from the assumption that United States law (and United States constitutional norms) must apply. Thus, the court framed the issue for decision solely in U.S. constitutional terms: "What is at issue here is whether it is consistent with the Constitution and laws of the United States for another nation to regulate speech by a United States resident within the United States on the basis that such speech can be accessed by Internet users in that nation." ${ }^{93}$

Conceptualized in this way, the district court had little difficulty determining that enforcement of the French court order would violate the First Amendment, concluding both that the French judgment constituted impermissible viewpoint discrimination and that it was unconstitutionally vague. The court therefore concluded that a United States court could not have issued such an order in the first instance without violating constitutional free speech norms. ${ }^{94}$ But of course, in a judgment recognition case, that is not the appropriate inquiry. Indeed, in the domestic context the Full Faith and Credit Clause requires recognition of judgments that might be illegal in the state where recognition is sought. ${ }^{95}$ Thus, the real question is whether this is the type of judgment that should be recognized, not whether the court could have issued the ruling as an original matter.

To its credit, the district court did include a brief discussion of the judgment recognition issue in a section titled "Comity." And the

\footnotetext{
${ }^{92}$ Yahoo!, Inc. v. La Ligue Contre Le Racisme Et L'Antisémitisme, 169 F. Supp. 2d 1181, 1186 (N.D. Ca. 2001), rev'd on other grounds, 379 F.3d 1120 (9th Cir. 2004), reh'g granted en banc, 399 F.3d 1010 (9th Cir. 2005).

${ }_{93} I d$. at 1186 (emphasis omitted).

${ }^{94}$ Id. at $1189-90$.

${ }^{95}$ See, e.g., Estin v. Estin, 334 U.S. 541, 546 (1948) (finding that the Full Faith and Credit Clause "ordered submission ... even to hostile policies reflected in the judgment of another State, because the practical operation of the federal system, which the Constitution designed, demanded it”); Milwaukee County v. M.E. White Co., 296 U.S. 268, 277 (1935) ("In numerous cases this Court has held that credit must be given to the judgment of another state, although the forum would not be required to entertain the suit on which the judgment was founded . . .."); Fauntleroy v. Lum, 210 U.S. 230, 237 (1908) (holding that the judgment of a Missouri court was entitled to full faith and credit in Mississippi even if the Missouri judgment rested on a misapprehension of Mississippi law).

${ }^{96}$ Yahoo!, 169 F. Supp. 2d at 1192-93.
} 
court acknowledged that "United States courts generally recognize foreign judgments and decrees unless enforcement would be prejudicial or contrary to the country's interests." ${ }^{\prime 97}$ Yet, after reiterating that the French judgment "clearly would be inconsistent with the First Amendment if mandated by a court in the United States," ${ }^{, 98}$ the district court judge concluded that, because the foreign order would unconstitutionally chill speech occurring within U.S. borders, "the principle of comity is outweighed by the Court's obligation to uphold the First Amendment." ${ }^{, 99}$

Thus, while ostensibly addressing principles of judgment recognition, the court ultimately returned to the idea that if a judgment would be unconstitutional if issued in the United States, enforcing that judgment also would be unconstitutional, or at least sufficiently contrary to state interests as to overwhelm any principles of comity. By eliding the difference between issuing a judgment and enforcing a judgment, however, the court neglected to apply in more detail the various principles of judgment recognition or to consider more carefully those circumstances in which U.S. interests might not truly be threatened by the application of a foreign norm. ${ }^{100}$

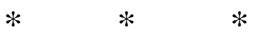

${ }^{97} I d$. at 1192 .

${ }^{98} I d$.

${ }^{99} I d$. at 1193 .

${ }^{100}$ A three-judge panel of the Ninth Circuit reversed, but it did so on jurisdictional grounds, without reaching the judgment recognition issue. Yahoo!, Inc. v. La Ligue Contre Le Racisme Et L'Antisémitisme, 379 F.3d 1120, 1121 (9th Cir. 2004), reh'g granted en banc, 399 F.3d 1010 (9th Cir. 2005). The appellate court decision did include some language suggesting skepticism about Yahoo!'s position. Indeed, the court went so far as to observe that, because Yahoo! "obtains commercial advantage from the fact that users located in France are able to access its website" and because Yahoo! even displays banner advertisements in French to French users, the company is obtaining "benefit from the fact that its content may be viewed around the world" and should therefore not be shielded from the concomitant costs of such activities. Id. at 1126 . The court refused to reach the issue of recognition, however, deciding instead that until the French plaintiffs actually sought enforcement of the order in the United States, they had insufficient contacts with the United States to justify jurisdiction. Id. at 1123 . Thus, though framed in the language of jurisdiction, the appellate court ruling seems to rest primarily on the idea that Yahoo!'s request for a declaratory judgment was not ripe for review in the absence of any indication that the French plaintiffs were actually seeking to enforce the order. See id. ("Jurisdiction may be obtained, and the First Amendment claim heard, once [the French parties] ask a U.S. district court to enforce the French judgment. As of yet, the organizations have declined to do so."). The Ninth Circuit has agreed to rehear the case en banc, 399 F.3d 1010, but as of this writing the full court has not yet issued a ruling. 
It is not that the results in any of these cases are necessarily so egregious (though I will have more to say about the outcomes later in this Essay). What is particularly troubling, however, is the failure of these courts even to think of the cases before them as true conflict-oflaws cases. As a result, nearly all of the conceptual and practical considerations that tend to arise in conflicts cases (as well as the voluminous scholarship on the subject) are ignored, and the truly transnational dimension of these cases is given short shrift. If nothing else, then, we need to go back to first principles, revisit the conflicts literature, and consider whether the insights gleaned there will provide a more nuanced vision of how best to approach these cases. The rest of the Essay takes up this task.

\section{Articulating a Cosmopolitan Vision of ChOice OF LAW}

Twentieth-century American choice-of-law theory has generally been divided into three primary movements: the "vested rights" approach associated with Joseph Beale, ${ }^{101}$ the "governmental interests" theory associated with Brainerd Currie, ${ }^{102}$ and the substantive law method championed (in various forms) by Arthur von Mehren, ${ }^{103}$ Friedrich Juenger, ${ }^{104}$ Luther McDougal, ${ }^{105}$ and others. The strengths

${ }^{101}$ See generally RESTATEMENT (FIRST) OF CONFLICT OF LAWS (1934) (featuring Beale as Reporter for the volume); JOSEPH BEALE, A TREATISE ON CONFLICT OF LAWS (1934).

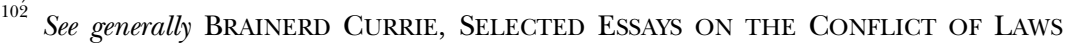
(1963).

${ }^{103}$ See, e.g., Arthur Taylor von Mehren, Special Substantive Rules for Multistate Problems: Their Role and Significance in Contemporary Choice of Law Methodology, 88 HARV. L. REv. 347, 371 (1974) [hereinafter von Mehren, Special Substantive Rules for Multistate Problems] (arguing that by adopting a substantive approach, "choice of law theory and practice could ... take a large step toward resolving the ancient conflict between the objectives of aptness and of decisional harmony"); see also Arthur Taylor von Mehren, Choice of Law and the Problem of Justice, LAW \& CONTEMP. PrOBS., Spring 1977, at 27, 43 [hereinafter von Mehren, Choice of Law] (suggesting that "functional approaches" to choice of law issues achieve "a higher quality of ... justice" than more traditional choice-of-law methods).

104 See, e.g., Friedrich K. Juenger, ChOice of LAW AND Multistate Justice (1993) (calling for the adoption of a substantive approach based on qualitatively evaluating conflicting laws to bring predictability and uniformity to conflicts thinking); Friedrich K. Juenger, Mass Disasters and the Conflict of Laws, 1989 U. ILL. L. REV. 105, 126 (suggesting that in a mass disaster case, the court look to "the place of the tortfeasor's conduct; ... the place of injury; ... [and] the home state of each party" and "select from the laws of these jurisdictions the most suitable rule of decision"); Friedrich K. Juenger, The Need for a Comparative Approach to Choice-of-Law Problems, 73 TUL. L. REV. 1309, 1317 (1999) ("Instead of determining whether a contract is French or New York in nature or whether the New York rule on consideration applies, the substantive law 
and weaknesses of each of these approaches have been much rehearsed in the conflicts literature, and it is far beyond the scope of this Essay to attempt a full description of any of these theories. Therefore, this Section simply highlights those aspects of each theory that contribute to (or contrast with) the articulation of a cosmopolitan vision of choice of law.

\section{A. Territorialism}

Beale's vested rights theory-which dominated U.S. conflicts thinking in the first part of the twentieth century and was embodied in the Restatement (First) of Conflict of Laws-derived from a strictly territorial notion of sovereign power. ${ }^{106}$ Accordingly, vested rights focused only on the physical location of the essential act that, at least to Beale, constituted the cause of action. Beale looked to the place of the tort ${ }^{107}$ or the place of contracting, ${ }^{108}$ or the location of the property at issue. $^{109}$ Having "localized" the cause of action, he concluded that only the state where the cause of action "vested" could apply its law to the dispute. ${ }^{110}$

These attempts to localize a cause of action were problematic from the outset. Some of the difficulties were practical. First, Beale

approach asks whether there is an interstate or international rule on point."); see also Friedrich K. Juenger, American Conflicts Scholarship and the New Law Merchant, 28 VAND. J. TRANSNAT'L L. 487, 496 (1995) (identifying other scholars who support a substantive law approach).

${ }^{105}$ See, e.g., Luther L. McDougal III, "Private" International Law: Ius Gentium Versus Choice of Law Rules or Approaches, 38 AM. J. COMP. L. 521, 536-37 (1990) (“[T] he best way to take appropriate account of substantive policies is to do so directly through the development and application of transnational laws.").

${ }^{106}$ See 1 BEALE, supra note 101, at 311-12 (Because "the power of a state is supreme within its own territory, no other state can exercise power there," and thus "[i]t follows generally that no statute has force to affect any person, thing, or act... outside the territory of the state that passed it.").

107 See RESTATEMENT (FIRST) OF CONFLict OF LAws $\$ 378$ ("The law of the place of wrong determines whether a person has sustained a legal injury.”).

${ }^{108}$ See 2 BEALE, supra note 101, at 1091 (arguing that questions of contract validity can generally be determined "by no other law than that which applies to the acts, that is, by the law of the place of contracting. ... If ... the law of the place where the agreement is made annexes no legal obligation to it, there is no other law which has power to do so.").

${ }^{109}$ See 2 id. at 938 (finding that immovable property, "being unable to be taken away from the state in which [it is located], must always in the last analysis be governed by the laws of that state").

${ }^{110}$ See $1 \mathrm{id}$. at 64 (" $[\mathrm{T}]$ he chief task of the Conflict of Laws [is] to determine the place where a right arose and the law that created it.”). 
was forced to create many exceptions to his general rules. Thus, although contracts were generally governed by the law of the place where the offer was accepted, if the issue in the case concerned the legality, validity, or scope of the performance of the contract (rather than the fact of the contract itself), then the proper forum was the place of performance, not the place of contracting. ${ }^{11}$ Second, it was difficult to determine whether a particular case fell within the scope of the general rule or the exception. For example, it is often far from obvious whether a contract issue actually concerns formation or performance. Likewise, "[h] ow is a judge deciding a tort case to know whether the issue is one of standard of care-governed by the law of the place of injury-or of duty or privilege-governed by the law of the place where the injurious conduct occurred?"112 Third, Beale's system allowed judges to characterize issues as contracts or torts and therefore avoid applying unpalatable laws. ${ }^{13}$

But even apart from these pragmatic difficulties, there are several other more fundamental objections to the vested rights approach, and these objections turn out to be particularly important for generating a cosmopolitan understanding of choice of law. First, the singleminded focus on territoriality is problematic. This is partly because Beale had difficulty justifying why the territorial location of only one event in a complicated set of transactions should determine the law to be applied. For example, in the oft-discussed case of Alabama Great Southern Railroad v. Carroll, ${ }^{114}$ an employee was injured when a train coupling failed. The vested rights theory held that the relevant law was that of the state where the injury occurred. ${ }^{115}$ However, given that

\footnotetext{
111 See RESTATEMENT (FIRST) OF CONFLICT OF LAWS $§ 360$ (1934) (outlining provisions in case of illegality of performance).

112 LEA BRILMAYER, CONFLICT OF LAWS 24 (1995).

${ }^{113}$ For a discussion of the problems inherent in "characterization," see, for example, Albert A. Ehrenzweig, A Treatise on the Conflict of LAWs $§ 108$ (1962) (noting that what is accomplished through characterization could be achieved more directly through other legal methods); ROBERT A. LEFLAR, AMERICAN CONFLICTS LAW $\$ \S$ 87-88 (3d ed. 1977) (calling characterization a "gimmick" and a "result-selection device"); Joseph M. Cormack, Renvoi, Characterization, Localization and Preliminary Question in the Conflict of Laws, 14 S. CAL. L. REV. 221, 223-40 (1941) (discussing both primary and secondary characterization); Ernest G. Lorenzen, The Qualification, Classification, or Characterization Problem in the Conflict of Laws, 50 YALE L.J. 743, 743-48 (1941) (providing a useful summary of both continental and Anglo-American criticisms of characterization in the conflict of laws).

114 So. 803 (Ala. 1892).

115 See RESTATEMENT (FIRST) OF CONFLICT OF LAWs $\$ \S 377-78$ (1934) (explaining that the place of wrong is where the last act occurred, and the law of that forum governs the tort).
} 
the negligence took place elsewhere, the choice of the place of accident seems arbitrary. Similarly, it may be difficult to determine when and where an injury takes place (for example in a toxic tort case), and again the state where the person happens to be when the first symptoms appear seems relatively unimportant. ${ }^{116}$ Yet, under Beale's approach such a determination is the only relevant factor in choice-of-law analysis. Thus, even if one agreed that territorialism should be the criterion for choice of law, it is not at all clear how best to choose the appropriate territorial nexus, and Beale's mechanical rules seem to lack substance.

Moreover, the focus on territoriality by definition ignores important nonterritorial factors, such as community affiliation. For example, two parties who are domiciled in one state could avoid a local contract rule by crossing the border, entering into the contract, and returning. ${ }^{117}$ This is not at all hypothetical in the modern world of offshore regulatory havens, where corporations frequently attempt to avoid various forms of governmental control by changing their territorial location. Even the United States government has, in recent years, attempted to evade U.S. law by locating military detention facilities in Guantánamo Bay, Cuba. ${ }^{118}$ A purely territorial approach, therefore, will have difficulty coping with a modern world where transactions and transportation across borders are so frequent. Indeed, although Beale treated as transcendental truth the idea that the state has complete and unchallenged authority within its own sphere and that no state, therefore, may meddle in another state's "local" affairs, ${ }^{119}$ we live today in a far more fluid world of jurisdictional assertions across territorial borders and entities that cause significant impact in far-away locations. $^{120}$ A purely territorial choice-of-law rule is unlikely to be satisfying in such a world. Accordingly, a cosmopolitan conception needs to acknowledge that people may have multiple community affiliations

${ }^{116}$ See, e.g., BRILMAYER, supra note 112, at 25-26 (discussing such difficulties).

117 See CURRIE, supra note 102, at 87-88 (discussing this scenario).

118 See Brief for the Respondents at 14, Rasul v. Bush, 124 S. Ct. 2686 (2004) (Nos. 03-334, 03-343) (arguing that because detainees "are being held by the U.S. military outside the sovereign territory of the United States[,] . . U.S. courts lack jurisdiction to consider claims filed on [their] behalf"). The U.S. Supreme Court rejected this argument. See Rasul v. Bush, 124 S. Ct. 2686, 2698 (2004) (concluding that no Supreme Court precedent "categorically excludes aliens detained in military custody outside the United States from the 'privilege of litigation' in U.S. courts").

${ }^{119}$ See supra text accompanying notes 106-110 (outlining Beale's territorial approach).

${ }^{120}$ See generally Berman, supra note 9 (discussing challenges to jurisdictional rules that are based on fixed conceptions of territorial borders). 
beyond simply their territorial location at a particular moment in time, and therefore it might be appropriate for nonlocal law to apply to their transactions, at least under some circumstances.

Second, Beale assumed that only one state's law could ever apply to any particular transaction, a strikingly uncosmopolitan view. To Beale, this idea was essentially a corollary to his territorialism. If states have complete and unfettered sovereign power within their borders and no power beyond those borders, then as long as a cause of action could be "located" somewhere, it necessarily followed that only one state's law could apply. ${ }^{121}$ Even under Beale's scheme, however, courts often evaded this requirement because Beale accorded to the forum state the ability to apply its own procedural law even if the vested rights approach dictated that foreign substantive norms must govern. ${ }^{122}$ Thus, any judge wishing to apply local law to at least part of the dispute needed only to characterize the legal issue as "procedural." Even more importantly, the single-state approach rigidly rejects the reality that, in a complex multistate transaction, the norms of multiple states are obviously implicated. Therefore, arbitrarily choosing one to the exclusion of the others seems inappropriate. And again, to the extent that pure territorialism was arbitrary in the early twentieth century, it seems even more problematic today to insist that only one state's norms should apply to the huge variety of multistate transactions possible in a globalized world. In order to avoid such limitations, a cosmopolitan approach can recognize the possibility that norms of multiple states might apply to different parts of the dispute or that rules might ultimately be blended to account for the variety of normative systems implicated in a given transaction.

A third common objection to vested rights, however, may be misplaced. Although Beale claimed to be a positivist who was merely describing how U.S. cases had generally been resolved, there can be little doubt that his vested rights approach was based on his own legal reasoning about when state power is legitimate. As Lea Brilmayer has pointed out, "[h]e was not merely an encyclopedist of specific doctrines and precedents but a rationalizer and a theorist of what the law

121 See BRILMAYER, supra note 112, at 28-29 ("Beale wished to assign to a single state the right to regulate a controversy, on the theory that the rights vested in one state only. This provided the basis for choice that was needed to make his multilateral system work.").

${ }^{122}$ See Restatement (FiRst) OF CONFLiCT OF LAws $§ 585$ (1934) ("All matters of procedure are governed by the law of the forum."). 
ought to be." ${ }^{123}$ Indeed, Beale consistently derived his principles from his own view of the nature of law, and the cases he cited often seem more like illustrations of his theory than data points from which his theory was drawn. Moreover, even Beale explicitly noted that his theory could sometimes diverge from the common law reality. ${ }^{124}$ Thus, the vested rights approach is not grounded in positive law, but is instead an a priori methodology. ${ }^{125}$ Accordingly, it chooses the applicable law based on principles that are not necessarily contained in the law of any particular state. In addition, the choice-of-law decision is made completely independently of the substantive norms that might apply.

This seemingly metaphysical strain to vested rights provoked vehement criticism from later scholars. But, as we will see, it may be impossible to develop any choice-of-law regime through purely positive law because in order to apply positive law one must choose which state's positive law should apply, and that choice by definition cannot be made pursuant to any single state's positive law. ${ }^{126}$ Moreover, why is it necessarily problematic for a choice-of-law regime to be based on principles that operate independently from the substantive law that will result? After all, the choice-of-law decision turns on when it is "legitimate" (whatever that word might mean) for a community to apply its norms to a dispute. Such issues of legitimacy will necessarily revolve around community definition, affiliation, and disputes about conflicting claims to governing authority. And none of those questions needs to involve the content of the various legal rules at all.

123 BRILMAYER, supra note 112 , at 21.

${ }^{124}$ See 1 BEALE, supra note 101, at 29 (acknowledging that some of his legal principles "have not the sanction of judicial decision").

${ }^{125}$ See, e.g., BRILMAYER, supra note 112, at 32 (noting that although Beale claimed to be deriving his conflicts theory from judicial opinions and state law, " $[\mathrm{h}]$ is methods belied this assertion").

${ }^{126}$ Larry Kramer, while deriding both Beale and Currie for separating the decision regarding choice of law from the decision on the merits of the suit, maintains that, in multistate cases, as in domestic cases, there is no need to make a prior "choice" of law; rather, the relevant question is "whether some rule of positive law gives the plaintiff a right to recover." Larry Kramer, Interest Analysis and the Presumption of Forum Law, 56 U. CHI. L. REV. 1301, 1310 (1989). Once such a rule is identified, however, the court will still need to decide whether the rule appropriately applies. And while Kramer sees that process as no different from a domestic case where plaintiff and defendant are relying on different lines of legal authority, he does acknowledge that both parochial governmental interests and broader conflicts interests are relevant in a multistate case. Thus, even in Kramer's framework it still seems as if the process of identifying such governmental or conflicts interests will require application of some a priori principles about how best to identify those interests. 
Thus, a cosmopolitan approach to choice of law clearly rejects the territorialism of vested rights as well as the idea that only one state's law could ever apply to any particular transaction. But cosmopolitanism borrows from vested rights a willingness to make choice of law an a priori inquiry. The only difference is that, instead of an a priori inquiry attempting to "localize" a transaction in territorial space, cosmopolitanism would engage in an a priori debate about community affiliation, definition, and effects in order to determine whether a given community may appropriately (or legitimately) apply its norms to a dispute. Further, cosmopolitanism shares with vested rights the idea that this a priori determination is necessarily based on issues that are conceptually distinct from the substantive norms that might be applied.

\section{B. Parochialism}

Brainerd Currie, building on legal realism, argued that choice of law must focus on specific policy aims, and not on the transcendent formal categories that Beale espoused. ${ }^{127}$ In addition, Currie echoed positivist concerns that choice-of-law rules should not be divined from "general principles" unmoored to a particular state. ${ }^{128}$ Rather, Currie argued that courts should look only to the rules of actual statesanctioned law. ${ }^{129}$ Thus, instead of starting from the idea that legal rights could "vest" based on formal definitions even before a particular law was deemed to apply, Currie based his theory on the premise that a court granted power by the legislature of a particular state generally applies that state's law. ${ }^{130}$ Indeed, Currie argued that so long as the forum government is deemed to have an "interest" in the dispute, its law should always govern, regardless of the multistate character of the events at issue in the case. ${ }^{131}$ And although Currie subsequently

${ }^{127}$ See CURRIE, supra note 102, at 181 ("The courts simply will not remain always oblivious to the true operation of a system that, though speaking the language of metaphysics, strikes down the legitimate application of the policy of a state.").

${ }^{128}$ See id. at 434 (criticizing the idea that choice of law is "a thing apart, a detached science of how laws operate in space; so conceived, it is an international science, transcending local concerns for the most part").

${ }^{129}$ See id. at 627 ("[T] he method I advocate is the method of statutory construction, and of interpretation of common-law rules, to determine their applicability to mixed cases.”).

${ }^{130}$ See id. at 75 (stating his presumption in favor of forum law).

${ }^{131}$ For example, Currie wrote that

Justice between the parties requires a decision on the merits. And where

should the New York court look for a rule of decision that will do justice be- 
softened this position somewhat in response to critics, ${ }^{132}$ his governmental interest approach remains suffused with a parochial bias in favor of forum law.

Moreover, at least in the pure form in which Currie first articulated interest analysis, he made it clear that if the forum state has an interest in applying its own law to the dispute, the existence of that interest always means that forum law will apply, even if the competing state also has an interest. ${ }^{133}$ Thus, the only time that forum law does not apply, under Currie's scheme, is when the forum state has no interest in applying its legal rules to the events at hand. Currie called such cases "false conflicts" and therefore did not really treat them as conflict-of-laws cases at all. ${ }^{134}$

Of course, Currie's approach ultimately turns on how one defines a governmental "interest." Currie argued that the judge must first ascertain the domestic policy that the legislature seeks to promote. Then, the inquiry turns to whether those policies would be advanced by applying the law to the particular facts under consideration. ${ }^{135}$ Only then can one determine if a state has an "interest" in having its law applied.

In practice, however, Currie defined governmental "interests" quite narrowly. Indeed, if one parses Currie's application of his choice-of-law theory, it becomes clear that the sole determinant of a governmental interest is whether application of a particular law will help a citizen of the state under consideration actually to win the lawsuit at hand. A state is therefore deemed to have an interest only in helping its citizens win. If, on the other hand, application of a state law would not help the citizen of that state to win, Currie concluded that the state has no interest, and the court is free to apply foreign law.

tween the parties but to the body of principle and experience which has served that purpose, as well as the ends of governmental policy, for the people of New York in their domestic affairs? Id. at 65 .

${ }^{132}$ See Brainerd Currie, The Disinterested Third State, 28 LAW \& CONTEMP. Probs. 754,757 (1963) (suggesting that, if a true conflict is found, a court might take a second look at the local policy it had uncovered to see if a more "restrained" view might be possible).

${ }^{133}$ CURRIE, supra note 102, at 184.

${ }^{134}$ See Brainerd Currie et al., Comments on Babcock v. Jackson, a Recent Development in Conflict of Laws, 63 Colum. L. REV. 1212, 1242 (1963) ("If the court finds that one state has an interest in the application of its policy in the circumstances of the case and the other has none, it should apply the law of the only interested state.").

${ }^{135}$ CuRRIE, supra note 102, at 183-84. 
One can see this narrow focus by studying Currie's most famous example, ${ }^{136}$ a hypothetical set of variations on the well-known case Milliken v. Pratt. ${ }^{137}$ Milliken involved a contract between a buyer and seller of goods, under which the buyer's obligation had been guaranteed by his wife. At the time, Massachusetts had a law that invalidated such guarantees given by married women. The policy behind such a rule, supposedly, was to protect married women from being coerced by their husbands. But even assuming that a court has accurately identified the paternalistic Massachusetts policy, the question becomes how to translate the existence of such a policy into the existence of an interest in a particular case involving a contracting party from a state such as Maine, that does not have this rule. ${ }^{138}$ Analyzing Currie's various permutations on the Milliken fact pattern, it is clear that, so long as the married woman is from Massachusetts (and applying Massachusetts law would help her to win), Currie would find a Massachusetts interest. $^{139}$

Thus, in Currie's view, a government's interests for choice-of-law purposes extend only to helping its citizens win in the short term. Moreover, in a "true" conflict case, where the laws of each state help its respective citizens, Currie breaks the "tie" by again choosing forum law. ${ }^{140}$ Thus, a parochial analysis of interests joins with a parochial set of default rules to produce a narrow focus on simply the domicile of the parties and whether the relevant legal rules will help the domiciliary to win.

Interestingly, although Currie's approach grew out of American legal realism and its emphasis on policy justifications rather than formal rules, ${ }^{141}$ his focus on the parochial interests of a state actually

136 Id. at ch. 2.

137125 Mass. 374 (1878).

138 Cf. Herma Hill Kay, Theory Into Practice: Choice of Law in the Courts, 34 MERCER L. REV. 521, 540 (1983) (stressing the important difference between determining the relevant domestic policy that a legislature sought to promote, and finding that the state actually has sufficient connection to the dispute such that it has an interest in having its law applied).

${ }^{139}$ CURRIE, supra note 102, at ch. 2. Currie isolated four factors that might be relevant to the choice-of-law decision: the creditor's residence, the married woman's residence, the place of contracting, and the forum state. By varying these four factors, Currie developed sixteen hypothetical permutations and provided his choice-of-law conclusions for each. Id. at 82-83.

140 Id. at 119.

${ }^{141}$ Currie's critique of vested rights echoed earlier legal realist arguments. See generally David F. Cavers, A Critique of the Choice-of-Law Problem, 47 HARV. L. REV. 173 (1933); Walter Wheeler Cook, The Jurisdiction of Sovereign States and the Conflict of Laws, 
bears even more resemblance to a different school of realism: international relations realism. Although there has been little scholarly discussion about the possible connections between these two strands of "realist" thought, ${ }^{142}$ a consideration of international relations realism allows us to see possible limitations to Currie's understanding of governmental interests.

International relations realists, just like Currie, deny the existence of a "higher" set of legal norms that might limit the ability of a nationstate to pursue its own interests. Thus, just as Currie decried the use of a priori choice-of-law norms, the international relations realists reject the efficacy of international law norms as an independent check on the activities of states. Indeed, international relations realists have generally viewed such international law norms as largely irrelevant to the power politics that are seen as the true engine of norm development on the world stage. ${ }^{143}$ This approach assumes that states are motivated primarily by their parochial geopolitical interests and that international law is complied with only when it is in the interests of powerful states to do so. These powerful states may then coerce weaker states into accepting the regime, but in any event the particular norms of international law are largely immaterial. Even so-called "neorealists," who have substituted rational choice theory for a pure focus on power, nevertheless retain the emphasis on state interests.

31 Colum. L. Rev. 368 (1931); Walter Wheeler Cook, The Logical and Legal Bases of the Conflict of Laws, 33 Yale L.J. 457 (1924); Ernest G. Lorenzen, Territoriality, Public Policy and the Conflict of Laws, 33 YALE L.J. 736 (1924). Indeed, Currie himself wrote that Cook's realist assault on vested rights discredited that theory "as thoroughly as the intellect of one man can ever discredit the intellectual product of another." CURRIE, supra note 102, at 6 . On the other hand, at least one scholar has noted that, because Currie did not sociologically look to past decisions of courts but instead argued against the theoretical basis of those decisions, his "approach rested upon a conception alien to Legal Realism." Alfred Hill, The Judicial Function in Choice of Law, 85 COLUM. L. REV. 1585,1588 n.6 (1985).

${ }^{142}$ One useful consideration of this connection may be found in BRILMAYER, supra note 112 , at $41-46$.

${ }^{143}$ See, e.g., Jack Goldsmith, Should International Human Rights Law Trump U.S. Domestic Law?, 1 CHI. J. INT'L L. 327, 337 (2000) ("Nations that increase protection for their citizens' human rights rarely do so because of the pull of international law."); see also Francis A. Boyle, The Irrelevance of International Law: The Schism Between International Law and International Politics, 10 CAL. W. INT'L L.J. 193, 193-94 (1980) (arguing against the importance of international law); Robert H. Bork, The Limits of "International Law," NAT'L INTEREST, Winter 1989-90, at 3, 5 (same). Other examples of international relations realism include EDWARD HALlETT CARR, THE TwENTY YEARS' CRISIS 1919-1939 (Macmillan Press 1946) (1939); Hans J. MoRgenthau, POlitics AMONG Nations (5th ed. 1973); Hans J. Morgenthau, Positivism, Functionalism, and International Law, 34 AM. J. INT'L L. 260 (1940). 
They view states as unitary rational actors that seek primarily to insure their own preservation and dominate others. ${ }^{144}$ Such an emphasis acknowledges the efficacy of international law norms only to the extent that it is in the rational self-interest of states to acknowledge such norms. Thus, both governmental interest analysis and international relations realism reject the idea of a transcendent set of multistate legal norms in favor of a single-minded focus on the parochial interests of states. Moreover, both of these approaches usually define state interests narrowly to include only those that serve short-term goals.

Of course, in public international law the international relations realist perspective has received substantial criticism from those who see a more complicated process of norm development in the global arena. For example, some have focused on the idea of "transnational legal process," which provides a framework for understanding how countries may internalize international or transnational norms. ${ }^{145}$ Others have pointed to transnational governmental ${ }^{146}$ and nongovernmental $^{147}$ networks that create multistate regulatory policies. Promising new research has used institutional sociology to try to understand, in a more nuanced way, how nation-state bureaucracies are affected by the very fact that they are embedded in an international system. ${ }^{148}$ And, in general, a burgeoning field of scholarship is transforming international law's traditional focus on nation-states into a broader understanding of law and globalization. ${ }^{149}$ This scholarship

144 See, e.g., Kenneth N. WAltz, Theory of International Politics 118 (1979) (viewing states as "unitary actors who, at a minimum, seek their own preservation and, at a maximum, drive for universal domination").

${ }^{145}$ For discussion of the transnational legal process framework, see Harold Hongju Koh, How Is International Human Rights Law Enforced?, 74 IND. L.J. 1397 (1999); Harold Hongju Koh, Transnational Legal Process, 75 NEB. L. REv. 181 (1996); Harold Hongju Koh, Why Do Nations Obey International Law?, 106 YALE L.J. 2599 (1997) (reviewing ABram Chayes \& ANTONia HANDler Chayes, THE NeW SOVEREIGNTY: COMPLIANCE WITH INTERNATIONAL REGULATORY AGREEMENTS (1995)).

${ }^{146}$ See, e.g., ANNe-MArie Slaughter, A New WORLd Order (2004) (constructing a model for understanding governmental networks).

${ }^{147}$ See, e.g., Julie Mertus, From Legal Transplants to Transformative Justice: Human Rights and the Promise of Transnational Civil Society, 14 AM. U. INT'L L. REV. 1335, 134151, 1365-87 (1999) (discussing the increasing importance of transnational civil societies, and the corresponding effect on international human rights law).

148 See, e.g., Ryan Goodman \& Derek Jinks, Toward an Institutional Theory of Sovereignty, 55 STAN. L. REV. 1749 (2003).

${ }^{149}$ For an overview of this scholarship, see Paul Schiff Berman, From International Law to Law and Globalization, 43 COLUM. J. TRANSNAT'L L. 485 (2005); see also THE Globalization OF Justice (Paul Schiff Berman ed., forthcoming 2005) (collecting essays). 
recognizes that the interests of nation-states are affected by many actors in the world system, that rhetorical statements of international legal norms, even without formal enforcement power, have important impact on popular legal consciousness, and that states exercise soft power in part by demonstrating compliance with international norms. ${ }^{150}$

Many of these same critiques apply to Currie's idea of governmental interests as well. First, even if one is concerned only with purely power-driven state interest, one might easily imagine a state to have interests beyond simply allowing its citizen to win a particular case. Indeed, from a long-term geopolitical perspective, whether or not an individual citizen wins a lawsuit is actually of very little interest to a state. Instead, states may have an interest in being seen to comply with an agreed-upon international order. States benefit from a shared world system, with its interlocking set of reciprocal benefits and burdens. If a state is too parochial in pursuit of its short-term interests, it may damage its longer-term goals by creating a lack of trust in other states. ${ }^{151}$ As economists have long recognized, repeat players tend to benefit from cooperative rather than parochial behavior. ${ }^{152}$ Accord-

150 The Globalization OF Justice, supra note 149; Berman, supra note 149.

151 As Larry Kramer has pointed out, even if we assume that states are interested only in advancing the domestic policies underlying their particular laws, "[e]nforcing foreign law in some cases only may do this better than always enforcing forum law because it invites reciprocal action that advances forum policies in cases brought elsewhere." Larry Kramer, Return of the Renvoi, 66 N.Y.U. L. REV. 979, 1016 (1991). Kramer argues that "[i]f every state adopts the 'law of the forum' solution and enforces its law in true conflict cases, each state's policies will be advanced only in true conflicts litigated in that state's courts. But there is no guarantee that this will include even half the cases." Id. Likewise, Laurence Helfer and Graeme Dinwoodie observe that, though a country might pursue its objectives simply by mandating application of its law to all disputes, "a political unit might more rationally conclude that the best route to making its own internal policy values effective in the greatest possible number of multistate situations is to take into account more than proceedings before its own tribunals." Laurence R. Helfer \& Graeme B. Dinwoodie, Designing Non-National Systems: The Case of the Uniform Domain Name Dispute Resolution Policy, 43 WM. \& MARY L. REV. 141, 261 (2001). Accordingly, they observe, like Kramer, that

the courts of State $A$ may apply, or at least consider, the internal policies of State $B$ in the hope (and expectation) that the courts of State $B$ will consider the internal policy values of State $A$ in cases where State $A$ would have a strong interest in seeing its internal values applied.

Id.

152 See, e.g., Robert Axelrod, The Evolution of CoOperation 19-20 (1984) (describing "tit for tat" strategy as an example of repeat play that can produce cooperation even among self-interested individuals); see also David M. Kreps et al., Rational Cooperation in the Finitely Repeated Prisoners' Dilemma, 27 J. ECON. THEORY 245 (1982) (discussing the effect of repeat play on prisoner's dilemma games). 
ingly, a state that refuses to defer to foreign norms will likely find that its norms receive less deference from others in the future. Currie, therefore, ignores the possibility that states might benefit from establishing a system of multilateral choice-of-law rules that each state would obey rather than asking whether a state has a short-term interest in each particular case. ${ }^{153}$

Second, international law norms that limit unfettered nation-state sovereignty do not necessarily lose their normative power just because they are not themselves issued by entities that wield coercive power. Indeed, while Currie rejected Beale's vested rights approach in part because it derived its authority from legal principles unmoored to a particular state's law, many such unmoored legal principles end up having real effect in the world. Thus, Currie assumes that only state interests are relevant and further assumes that those interests are unaffected by the very fact that the state is part of an international system. But neither assumption is necessarily true. We could adopt a choice-of-law rule that takes the perspective not of an individual state but of the entire global legal system, and then try to resolve the choice-of-law question. Moreover, even from the perspective of an individual state, the very fact that it is part of an international system and subject to diplomatic and other pressures means that courts cannot effectively further state interests by parochially making sure that the law applied to any given multistate case will always benefit its own citizens.

Third, Currie cannot, in any event, avoid the problem of creating a priori choice-of-law norms unmoored to a state legal regime. This is because his governmental interest analysis necessarily looks to the domicile of the parties to determine whether a state has an interest in the dispute. But, we might ask, why is the domicile of the parties the most important connecting factor? Why not territory (as in vested rights) or some other potentially relevant rubric? The answer requires Currie to rely on some sort of normative judgment that precedes the choice-of-law decision itself. Thus, Currie's framework is as much an a

${ }^{153}$ Indeed, Currie's understanding of a governmental interest suffers from flaws that behavioral economists have identified in many forms of "intertemporal decision making." The idea is that decision makers systematically mispredict their own future preferences because they fail to appreciate the ways in which their long-term preferences may differ from their current ones. For a discussion of this phenomenon, see Shane Frederick et al., Time Discounting and Time Preference: A Critical Review, $40 \mathrm{~J}$. ECON. LIT. 351, 367-68 (2002). 
priori philosophical position as Beale's is, and cannot claim authority on the basis of being more connected to positive law. ${ }^{154}$

Finally, Currie's conception of a governmental interest tends to presuppose that the interest itself is a legitimate one for the government to pursue. For example, imagine that a given state took the position that its environmental protection statutes should apply to all citizens of the world because all citizens have a stake in a sustainable planet. Currie's interest analysis, by its terms, would need to give effect to this stated governmental interest. Yet in a case brought in that state involving two parties, neither of whom is a citizen of the state, one suspects that Currie would not insist on the application of forum law. Thus, whatever else one can say about governmental interest analysis, its scope seems to be derived from more general principles of legitimacy; it is not derived from legislative policy alone.

Nevertheless, despite these shortcomings, governmental interest analysis at least frees us from the rigid territorialism of vested rights and allows us to consider what the interests of states might be in a globalized multilateral system. We can therefore accept that a focus on interests is appropriate, without also accepting Currie's peculiarly narrow and parochial conception of such interests. Instead, a cosmopolitan vision can consider a broader set of governmental interests in being part of an interlocking world system of transnational regulation and multiple community affiliation.

\section{Substantivism}

Over the past few decades, several conflicts scholars have articulated (without fully developing) a distinct choice-of-law methodology that emphasizes the ability of judges to create special substantive rules in multistate cases. In 1974, Arthur von Mehren noted "the advantages, in certain multistate or multiple contact situations, of applying special rules that are not necessarily chosen from among provisions in the domestic law of any of the jurisdictions viewed as legitimately concerned with the resolution of the issues presented."

${ }^{154}$ See Kramer, supra note 126, at 1308 ("Currie ... made the same conceptual mistake he correctly accused traditional choice of law scholars of making: he treated 'choosing' the applicable law as a threshold inquiry distinct from 'applying' the chosen law.").

${ }^{155}$ von Mehren, Special Substantive Rules for Multistate Problems, supra note 103, at 348; see also von Mehren, Choice of Law, supra note 103, at 27, 38-40 (suggesting circumstances in which conflict of laws might best be resolved by a compromise among the values of the states involved). 
multijurisdictional rules, von Mehren suggested, would involve some sort of compromise among the values of the various states involved. ${ }^{156}$ Subsequently, Friedrich Juenger ${ }^{157}$ and Luther McDougal ${ }^{158}$ have also argued for the development and application of transnational laws fashioned by judges in multistate cases. And both have noted that this sort of substantive transnational law has historical antecedents dating back to the Roman Empire. ${ }^{159}$ Yet, although the substantive law method helps avoid binary either/or choice-of-law questions, the rise of nation-states-and the accompanying positivist idea that law must be clearly identified with a sovereign entity-pushed substantive approaches to the background.

Most recently, Graeme Dinwoodie has argued for a substantive law approach to international copyright disputes. ${ }^{160}$ Dinwoodie notes that courts in ordinary domestic disputes often must generate common law rules or glosses on legislative enactments. ${ }^{161}$ Indeed, any time a court adjudicates a dispute that does not involve a single governing rule the judge must select among possible models. ${ }^{162}$ For example, a court asked for the first time to consider the validity of a contract formed via telephone might look for guidance both to prior rules concerning face-to-face negotiations and to prior rules concerning negotiations by mail. ${ }^{163}$ As Dinwoodie points out, a court may consider both rules, but is not required to choose either; instead the court is likely to blend principles from each set of rules. ${ }^{164}$ Likewise, Dinwoodie argues, a court in a multistate dispute should not consider itself bound to choose one state's law over the other in toto; it should instead be free to craft a hybrid rule that reflects the interests of the multiple states and parties involved. ${ }^{165}$

${ }^{156}$ See von Mehren, Special Substantive Rules for Multistate Problems, supra note 103, at 359 (discussing states' willingness to deal in foreign courts).

${ }^{157}$ For a sample of Juenger's work, see sources cited supra note 104.

${ }^{158}$ See, e.g., McDougal, supra note 105.

159 See, e.g., JUENGER, supra note 104, at 8-10 (discussing the development of the ius gentium by the praetor peregrinus, starting around 242 B.C., to deal with cases involving non-Romans).

${ }^{160}$ Graeme B. Dinwoodie, A New Copyright Order: Why National Courts Should Create Global Norms, 149 U. PA. L. REV. 469, 542-80 (2000).

${ }^{161}$ See id. at 548 ("Courts ... often ... generate rules, rather than merely apply them ....").

${ }^{162} I d$.

${ }^{163} I d$.

${ }^{164} I d$.

${ }^{165} I d$. 
Such substantive lawmaking is particularly important in the international context. First, as Dinwoodie points out, "statutory rules enacted by a national legislature are rarely enacted with an eye to international disputes or conduct." ${ }^{166}$ And even when legislators actually consider activities abroad, they do so to pursue domestic policy priorities, with little consideration for multistate implications. ${ }^{167}$ Second, Dinwoodie argues that "a method that draws its applicable rule in international cases from an amalgam of national and international norms reflects the complex and interwoven forces that govern citizens' conduct in a global society." 168 Thus, a choice-of-law regime that forces binary choices requires citizens to be judged according to a single state norm in a world where those citizens affiliate with multiple states. Indeed, the mere fact that a dispute is multinational necessarily means that it implicates interests that are different from a purely domestic dispute. Accordingly, the substantive law method asks judges to consider these added factors and craft rules based on a variety of national and international legal norms.

The substantive method has much to recommend it. More than the other two approaches, it takes seriously the multistate nature of the dispute and seeks to find a way to reconcile the multiple communities potentially implicated. And, though it asks judges to engage in creative common law interpretation, which could result in a degree of unpredictability, such difficulties are likely to subside over time, as judges develop a series of international law norms that become relatively settled. Moreover, this method of creating international norms is likely to happen more rapidly than, for example, through the international treaty process. Thus, the substantive law method may allow legal rules to evolve more rapidly in the face of technological innovation. ${ }^{169}$

Nevertheless, I see at least two problems with the substantive approach. First, a method that asks judges to craft international or hybrid law unmoored to the positive law of their own states is likely to run into significant objections from the perspective of democratic legitimacy. Of course, it is true that any proposal that judges candidly engage in lawmaking is likely to raise a similar objection. But in this

166 Id. at 548-49.

167 Id. at 549.

168 Id. at 550.

169 See id. at 569 ("Using the substantive choice of law method as part of international lawmaking can supply the dynamism appropriately missing from classical public international lawmaking.”). 
context the critique is perhaps more trenchant because the substantive law method explicitly asks judges to look to legal sources external to the very sources of the courts' own authority and legitimacy. In this sense, those seeking to develop hybrid domestic/international norms might be better off arguing for an expansion of the idea of governmental interests. At least then the hybrid norms would be nominally grounded in the long-term interests of the state in which the court sits. Indeed, Dinwoodie himself acknowledges that governmental interest analysis, if expanded, could in fact be used to justify an approach like his substantive law method: "[I]f a legislature were consciously to address the policies by which it would seek to regulate international disputes before its courts, it might articulate a different policy that took into account the competing interests of other states as well as its own interest." ${ }^{170}$ Thus, expanding the idea of a governmental interest may raise fewer legitimacy concerns than the substantive law method, yet reach the same results.

Second, the substantive method, true to its name, focuses on the substance of the law to be applied rather than any external criteria that might be relevant to choosing the appropriate norms. Accordingly, although both vested rights and governmental interest analysis choose the applicable law based on a priori considerations- the "location" of the cause of action or the domicile of the parties-the substantive method emphasizes the need to choose governing norms rather a governing jurisdiction. But while proponents of the substantive law method tout this feature as an advantage, ${ }^{171}$ something is lost by not conducting a separate inquiry concerning prescriptive jurisdiction. After all, it seems reasonable to expect that the extent of the parties' relationships to the various states whose law might apply should have some independent bearing on the choice-of-law inquiry. Moreover, such an inquiry need not be either the formalist exercise envisioned by Beale or the parochial one advocated by Currie. Rather, choice of law could become the locus for debates about the varieties of community definition and affiliation present in the case and the degree to which issues of physical geographical location should remain salient as a guide to choice of law. If courts focus too much on the substance of the possible governing norms without conducting a separate choice-of-law inquiry, this important discussion could be elided or de-emphasized.

\footnotetext{
${ }^{170} I d$. at 549.

${ }^{171}$ See, e.g., id. at 547-48 (discussing the advantages of choosing rules or solutions rather than jurisdictions).
} 
To be fair, Dinwoodie himself seeks to avoid this problem. Indeed, in resolving a hypothetical transnational copyright dispute using the substantive law method, he asks courts to consider "all relevant interests-national, international, and postnational," ${ }^{172}$ an inquiry that presumably could include a discussion of community affiliation. Moreover, he masterfully dissects the various governmental interests, the trends in the law that courts might consider, and the hybrid solutions that could be devised. ${ }^{173}$ But even this admirable treatment of transnational choice of law still suffers from the substantive law method's insistence on combining the substantive analysis with the choice-of-law inquiry. Because of Dinwoodie's substantive focus, his discussion is almost completely confined to the various legal rules that might apply, their strengths and weaknesses, and the interests of the states involved. He does not, however, explicitly discuss the parties, nor does he engage in a discussion about the extent of the parties' affiliation with various normative communities or consider whether it is appropriate to see those parties as more connected to one of those communities in particular. Thus, while Dinwoodie's substantivism usefully employs a cosmopolitan framework when analyzing the norms in play, the substantive method tends (even in his version) to focus too little on the various possible definitions of community that might be available and the particular affiliations of the parties themselves.

Thus, although the substantive method appropriately asks judges to consider the distinctively international aspects of a dispute and to fashion creative hybrid solutions to multistate problems, it does so in a way that raises questions of democratic legitimacy and short-circuits important discussion about the appropriate scope of prescriptive jurisdiction. To avoid such problems, a cosmopolitan approach is grounded in an expanded conception of governmental interests and allows debate about the scope of a community's legal norms before addressing the norms themselves. Only through such debate can there be common law development of principles concerning the appropriate understanding of a legal community in a world of increasingly overlapping norm-generating groups.

\section{Cosmopolitanism}

Choice-of-law debates involve more than simply questions about which governing norms will be applied to a dispute. In addition, such

${ }^{172}$ Id. at 561.

${ }^{173}$ See id. at 561-69. 
debates address core issues of community definition and affiliation, particularly in a world where the significance of territorial location may be less salient than it once was. The advantage of cosmopolitanism as a choice-of-law framework is precisely the fact that cosmopolitanism seeks to understand these issues of multiple community affiliation. Indeed, cosmopolitanism starts from the premise that community affiliations are always plural and can be detached from mere spatial location. ${ }^{174}$ Thus, cosmopolitans recognize that " $[\mathrm{w}] \mathrm{e}$ are connected to all sorts of places, causally if not always consciously, including many that we have never traveled to, that we have perhaps only seen on television-including the place where the television itself was manufactured." 175

Cosmopolitanism can be traced at least as far back as the Stoics, who argued that each of us dwells in two communities: "the local community of our birth, and the community of human argument and aspiration that 'is truly great and truly common, in which we look neither to this corner nor to that, but measure the boundaries of our nation by the sun." "176 Recognizing the dangers of factionalism that come from allegiance to the political life of a group, the Stoics contended that only by placing primary allegiance in the world community can mutual problems be addressed.

Martha Nussbaum has recently elaborated on the Stoic ideal in an essay touting the cosmopolitan perspective. According to Nussbaum, cosmopolitanism does not require one to give up local identifications, which, she acknowledges, "can be a source of great richness in life."177 Rather, following the Stoics, she suggests that we think of ourselves as surrounded by a series of concentric circles:

The first one encircles the self, the next takes in the immediate family, then follows the extended family, then, in order, neighbors or local groups, fellow city-dwellers, and fellow countrymen-and we can easily

${ }^{174}$ For a sampling of the scholarship in this area, see generally JESSICA BERMAN, MOdernist Fiction, COSMOPOLITANISM, AND THE POLITICS OF COMMUNiTy 1-27 (2001); Cosmopolitics: Thinking AND FEeling BeyOnd THE NATION (Pheng Cheah \& Bruce Robbins eds., 1998) [hereinafter COSMOPOLITICS]; GLOBALIZATION (Arjun Appadurai ed., 2001); Ulf Hannerz, Transnational Connections: Culture, People, Places (1996); Martha C. Nussbaum with Respondents, For love of Country: Debating the Limits of PAtriotism (Joshua Cohen ed., 1996); BRUCE ROBBINS, FEELING GLOBAL: INTERNATIONALISM IN DISTRESS (1999).

${ }^{175}$ Bruce Robbins, Introduction Part I: Actually Existing Cosmopolitanism, in Cosmopolitics, supra note 174, at 1, 3 .

${ }^{176}$ Martha C. Nussbaum, Patriotism and Cosmopolitanism, in NussBaum WITH RESPONDENTS, supra note 174, at 2, 7 (quoting the Roman playwright Seneca).

${ }^{177} I d$. at 9 . 
add to this list groupings based on ethnic, linguistic, historical, professional, gender, or sexual identities. Outside all these circles is the largest one, humanity as a whole. ${ }^{178}$

Moreover, we need not relinquish special affiliations and identifications with the various groups. Indeed, " $[w]$ e need not think of them as superficial, and we may think of our identity as constituted partly by them." ${ }^{179}$ But, Nussbaum argues, "we should also work to make all human beings part of our community of dialogue and concern, base our political deliberations on that interlocking commonality, and give the circle that defines our humanity special attention and respect.",180

In this vision, people could be "cosmopolitan patriots," ing their responsibility to nurture the culture and politics of their home community, while at the same time recognizing that such cultural practices are always shifting as people move from place to place. "The result would be a world in which each local form of human life was the result of long-term and persistent processes of cultural hybridization-a world, in that respect, much like the world we live in now." $" 182$

Iris Young has used the ideal of the "unoppressive city" as a model for a similarly multifaceted understanding of community. ${ }^{183}$ She argues that "community" is always a politically problematic term because "those motivated by it will tend to suppress differences among themselves or implicitly to exclude from their political groups persons with whom they do not identify." ${ }^{\text {"18 }}$ Thus "[t]he desire for community relies on the same desire for social wholeness and identification that underlies racism and ethnic chauvinism on the one hand and political sectarianism on the other." ${ }^{185}$ Instead, Young envisions ideal city life as the "'being-together' of strangers." 186 These strangers may remain

$178 \mathrm{Id}$.

179 Id.

$180 \mathrm{Id}$.

181 Kwame Anthony Appiah, Cosmopolitan Patriots, in Cosmopolitics, supra note 174 , at 91

182 Id. at 92.

183 See Iris Marion Young, The Ideal of Community and the Politics of Difference, in FEMINISM/POSTMODERNISM 300, 317 (Linda J. Nicholson ed., 1990) ("Our political ideal is the unoppressive city."); see also Jerry Frug, The Geography of Community, 48 STAN. L. REV. 1047, 1048-49 (1996) (invoking Young's ideal city to reclaim the idea of community as "the being together of strangers," rather than limiting community to "feelings of identity or unity").

${ }^{184}$ Young, supra note 183, at 300.

185 Id. at 302.

${ }^{186}$ Id. at 318. 
strangers and continue to "experience each other as other." deed, they do not necessarily seek an overall group identification and loyalty. Yet, they are open to "unassimilated otherness." 188 They belong to various distinct groups or cultures and are constantly interacting with other groups. But they do so without seeking either to assimilate or to reject those others. Such interactions instantiate an alternative kind of community, ${ }^{189}$ one that is never a hegemonic imposition of sameness but that nevertheless prevents different groups from ever being completely outside one another. ${ }^{190}$ In a city's public spaces, Young argues, we see glimpses of this ideal: "The city consists in a great diversity of people and groups, with a multitude of subcultures and differentiated activities and functions, whose lives and movements mingle and overlap in public spaces."191 In this vision, there can be community without sameness, shifting affiliations without exclusion.

Although Young does not refer to her vision as cosmopolitan, it fits comfortably within the understanding of community affiliation I sketch here. Cosmopolitanism is emphatically not a model of international citizenship in the sense of international harmonization and standardization, but instead is a recognition of multiple refracted differences where (as in Young's ideal city) people acknowledge links with the "other" without demanding assimilation or ostracism. Cosmopolitanism seeks "flexible citizenship," mitted to shift identities amid a plurality of possible affiliations and allegiances. These allegiances could also include nonterritorial communities, such as those found in Internet chat rooms. The cosmopoli-

187 Id.

${ }^{188} I d$. at 319.

${ }^{189}$ Young resists using the word "community" because of the "urge to unity" the term conveys, but acknowledges that "[i]n the end it may be a matter of stipulation whether one chooses to call" her vision "community." Id. at 320; see also Frug, supra note 183, at 1049 ("Unlike Young, I do not cede the term community to those who evoke the romance of togetherness.").

${ }^{190}$ See Young, supra note 183, at 319 (positing that a group of strangers living side by side "instantiates social relations as difference in the sense of an understanding of groups and cultures that are different, with exchanging and overlapping interactions that do not issue in community, yet which prevent them from being outside of one another").

${ }^{191} I d$.

192 See Ainwa Ong, Flexible Citizenship: The Cultural Logics of TRANSNATIONALITY 6 (1999) (describing how "the cultural logics of capitalist accumulation, travel, and displacement that induce subjects to respond fluidly and opportunistically to changing political-economic conditions" foster a form of transnationality she calls "flexible citizenship"). 
tan worldview shifts back and forth from the rooted particularity of personal identity to the global possibility of multiple overlapping communities. "[I] nstead of an ideal of detachment, actually existing cosmopolitanism is a reality of (re)attachment, multiple attachment, or attachment at a distance." ${ }^{, 193}$

A cosmopolitan conception of choice of law might at first seem an oxymoron because cosmopolitanism is often equated with universalism. ${ }^{194}$ And of course, if we constructed one universal "world community" with one set of governing rules, there would never need to be a "choice of law" in the sense that conflict-of-laws scholars use the term. Yet, the cosmopolitan worldview I am describing, while eschewing a strict reliance on territorial location and geographical borders, also rejects the goal of universalism. Although the vision of one world community is attractive in its idealism, it strikes me as misguided for several reasons. First, it tends to require that we see ourselves primarily as citizens of the world and therefore tends to dissolve the multirootedness of community affiliation into one global community. Second, it fails to capture the extreme emotional ties people still feel to distinct transnational or local communities. ${ }^{195}$ Thus, universalism may ignore the very attachments people hold most deeply. Third, as Anupam Chander has pointed out, the aspiration that we become solely citizens of the world is at least partly based on an internationalization of John Rawls's theory of justice ${ }^{196}$ and is therefore subject to the same criticism Rawls has long faced: that his theory assumes a self detached from the social and cultural context that makes such a self possible. ${ }^{197}$

193 Robbins, supra note 175 , at 3.

194 See, e.g., Viet D. Dinh, Nationalism in the Age of Terror, 56 FLA. L. REV. 867, 879 (2004) ("Rather than aspiring to universal cosmopolitanism, statelessness may well foster reversion to a selfish individualism" (emphasis added)); see also Bruce Ackerman, Rooted Cosmopolitanism, 104 ETHICs 516, 534 (1994) ("If I were a European right now, I hope I would have the guts to stand up for rootless cosmopolitanism: forget this nationalistic claptrap, and let us build a world worthy of free and equal human beings."); Anupam Chander, Diaspora Bonds, 76 N.Y.U. L. REV. 1005, (2001) ("The cosmopolitan model . . . dissolves the multirootedness of diasporas into a global identity.").

${ }^{195}$ See, e.g., Thomas M. Franck, Clan and Superclan: Loyalty, Identity and Community in Law and Practice, 90 AM. J. INT'L L. 359, 374 (1996) ("The powerful pull of loyalty exerted by the imagined nation demonstrates that, even in the age of science, a loyalty system based on romantic myths of shared history and kinship has a capacity to endure ....").

196 See Brian Barry, Statism and Nationalism: A Cosmopolitan Critique, 41 NomOs 12, 36 (1999) (noting that a number of philosophers take a global version of Rawls's theory of justice as their starting point).

${ }^{197}$ See Chander, supra note 194, at 1047 (criticizing cosmopolitanism because it embraces an "image of the self that removes the aspects that make the self special"). 
Fourth, an ongoing system of universal governing norms poses such a strong challenge to our current notions of nation-state sovereignty that, as a practical matter, it seems unlikely to be adopted widely in the foreseeable future. Fifth, and perhaps most importantly, in order to create a set of universal legal norms that overrides local variation, one needs to presuppose a world citizenry devoid of both particularist ties and normative discussion about the relative importance of such ties. Thus, universalism can cut off debate about the nature of overlapping communities just as surely as territorialism or parochialism does.

A cosmopolitan conception of choice of law, in contrast, makes no attempt to deny the multirootedness of individuals within a variety of communities, both territorial and nonterritorial. Indeed, the basic tenet of cosmopolitanism, as I define it, is the acknowledgment of multiple communities, rather than the erasure of all communities except the most encompassing. Thus, although a cosmopolitan conception of choice of law often seeks to acknowledge and accommodate transnational and international norms, it does not require a universalist belief in a single world community. ${ }^{198}$

A choice-of-law regime built on cosmopolitan principles, therefore, asks courts to consider the variety of normative communities with possible ties to a particular dispute. In doing so judges must see themselves as part of an interlocking network of domestic, transnational, and international norms. Recognizing the "complex and interwoven forces that govern citizens' conduct in a global society," courts can develop a jurisprudence that reflects this cosmopolitan reality.

Chander ascribes this position to cosmopolitanism. While I agree with his critique, I believe he is actually targeting what I call "universalism." As this Section makes clear, I view cosmopolitanism as the recognition of multiple attachments, not the desire for a single world citizenry.

${ }_{198}$ As Graeme Dinwoodie has pointed out:

$[\mathrm{O}]$ ne can strive for greater uniformity on certain matters without wholly undermining the local values that conflictual methodology sustains. Comparative knowledge and comparative method will contribute to a better understanding of when, and how, each of these sometimes competing values should be given greater weight. The project of comparativists therefore is not to reveal universal truths, nor merely destructively to declare that the individuality of perspective renders the discipline an irrelevance and common values a fraud.

Graeme B. Dinwoodie, International Intellectual Property: A Vehicle for Resurgent Comparativist Thought?, 49 AM. J. COMP. L. 429, 452 (2001).

${ }^{199}$ Dinwoodie, supra note 160 , at 550. 
Such a jurisprudence looks to a variety of possible legal sources. First, courts can consider the multiple domestic norms of nation-states affected by the dispute. In considering which national norms to give greatest salience, courts must consider the community affiliations of the parties and the effect of various rules on the polities of the affected states. Moreover, whereas most traditional choice-of-law regimes require a choice of one national norm, a cosmopolitan approach permits judges to develop a hybrid rule that may not correspond to any particular national regime. Second, international treaties, agreements, or other statements of evolving international or transnational norms may provide relevant guidance. Third, courts should consider community affiliations that are not associated with nation-states, such as industry standards, norms of behavior promulgated by non-governmental organizations, community custom, and rules associated with particular activities, such as Internet usage. Fourth, courts should take into account traditional conflicts principles. For example, a useful choice-of-law framework should not develop rules that encourage a regulatory "race to the bottom" by making it easy to evade legal regimes.

At first glance, this approach might seem similar to the one taken by the Restatement (Second) of Conflict of Laws, which permits courts to consult a "grab bag" ${ }^{200}$ of factors to reach a choice-of-law decision, including "the needs of the interstate and international system." deed, the Second Restatement's emphasis on finding the place with the "most significant relationship" to the dispute ${ }^{202}$ does at least turn the focus from pure territorial contacts to relationships. It is unclear, however, whether such "relationships" include affiliations that are neither citizenship-based nor territory-based. In contrast, cosmopolitanism would acknowledge such additional affiliations. The Second Restatement also maintains a series of Beale-like presumptions about the proper choice-of-law default rules for specific types of cases. ${ }^{203}$ These presumptions tend to be based on territoriality and may actually trump the more general (and more cosmopolitan) guidance about the needs of the interstate and international system. ${ }^{204}$ Thus, though

200 BRILMAYER, supra note 112, at 74.

201 RESTATEMENT (SECOND) OF CONFLICT OF LAWS $§ 6$ (1971).

${ }^{202}$ See, e.g., id. $\$ 145(1)$.

203 Compare, e.g., id. $\S 145$ (listing general principles for tort cases), with id. $\S 188$ (contract cases), and id. $\$ 193$ (insurance cases).

${ }^{204}$ See, e.g., Wood Bros. Homes, Inc. v. Walker Adjustment Bureau, 601 P.2d 1369, 1372-73 (Colo. 1979) (ruling that, because the presumptions in section 196 had not 
one could perhaps interpret the Second Restatement in a cosmopolitan way, the emphasis of the Restatement is distinctly different.

A cosmopolitan approach does, however, share some basic tenets with the Restatement (Third) of Foreign Relations Law. Section 403 of the Restatement sets forth a series of principles intended to combat judicial (or legislative) parochialism. These principles include many of the factors a cosmopolitan approach privileges. For example, section 403(2) (b) asks judges to consider "the connections, such as nationality, residence, or economic activity, between the regulating state and the person principally responsible for the activity to be regulated." ${ }^{205}$ Likewise, section 403(2)(f) cites "the extent to which the regulation is consistent with the traditions of the international system." 206 These, and the other nonexclusive "reasonableness" factors of section 403 would certainly be among the criteria for making a choice-of-law decision using a cosmopolitan framework. Thus, to some extent the cosmopolitan vision I sketch here draws upon the Third Restatement, and judges employing the Third Restatement approach could comfortably fit the cosmopolitan principles I describe into their customary analyses. Indeed, cosmopolitanism could even be seen to provide an additional justification for the Restatement's emphasis on "connections" between the regulating state and the relevant actor.

On the other hand, a cosmopolitan conception asks judges explicitly to focus on community affiliation, which may prompt a different sort of inquiry from the Restatement's more generalized call to reasonableness. Indeed, among the benefits of a cosmopolitan framework is that it makes conflict of laws the site for ongoing legal discussions about the changing nature of community, personal identification, and social conceptions of space, distance, and borders. Such discussions may be less likely if judges are purporting to apply simply a multifactor reasonableness standard. Thus, even if many cases would ultimately be decided the same way under either a cosmopolitan test or one derived from the Third Restatement of Foreign Relations, the inquiry may be (though of course need not be) significantly different.

Perhaps most importantly, because a focus on community affiliation may lead us to consider nonstate communities, a cosmopolitan framework is far more likely to allow a pluralist consideration of how norms generated outside of formal governmental channels may bind

\footnotetext{
been rebutted, the general principles in section 6 would not be considered).

${ }^{205}$ RESTATEMENT (THIRD) OF THE FOREIGN RELATIONS LAW OF THE UNITED STATES $§ 403$ (2) (b) (1987).

${ }^{206} I d$. at $\$ 403(2)$ (f).
} 
sub-, supra-, and transnational communities. Thus, cosmopolitanism may open conceptual space for what Andreas Fischer-Lescano and Gunther Teubner have called "an inter-systemic conflicts law, derived not from collisions between the distinct nations of private international law, but from collisions between distinct global social sectors. ${ }^{207}$ Articulating such a pluralist vision of conflict of laws is beyond the scope of this Essay, but at the very least cosmopolitanism allows us to begin thinking along these lines. In contrast, the Third Restatement of Foreign Relations, though it takes a significant step forward by asking judges to consider norms of antiparochialism when making choice-oflaw decisions, may ultimately be too state-centered to provide the theoretical underpinnings for conflict of laws in an era of diffused sovereignty. ${ }^{208}$

As mentioned previously, a cosmopolitan approach to choice of law borrows elements not only from the Third Restatement of Foreign Relations, but from each of the three major choice-of-law methods already discussed. ${ }^{209}$ While eschewing both Beale's rigid formalism and his reification of territorial location as the basis for choice-of-law decisions, cosmopolitanism does recognize the importance of thinking about choice of law separately from the substantive norm to be applied. Thus, courts employing a cosmopolitan approach should discuss the possibly relevant community affiliations and consider their relative importance before turning to an application of substantive law. In this way, choice of law becomes the terrain for debate about the proper scope of community dominion in an era when territorial borders no longer adequately delimit community boundaries.

Likewise, while rejecting Currie's parochial application of governmental interest analysis, a cosmopolitan approach is firmly grounded in an expanded notion of governmental interests. Indeed, as courts consider multiple community affiliations and develop hybrid rules for resolving multistate disputes, they do so not because they are ignoring the policy choices of their home state, but because they are effectuating their state's broader interest in taking part in a global community.

${ }^{207}$ Andreas Fischer-Lescano \& Gunther Teubner (Michelle Everson trans.), Regime-Collisions: The Vain Search for Legal Unity in the Fragmentation of Global Law, 25 MICH. J. INT'L L. 999, 1000 (2004) (internal quotation marks omitted).

${ }^{208}$ Cf. Adeno Addis, The Thin State in Thick Globalism: Sovereignty in the Information Age, 37 VAND. J. TRANSNAT'L L. 1, 85-104 (2004) (articulating a theory of state sovereignty that he calls "thin statism"); Anne-Marie Slaughter, The Real New World Order, FOREIGN AFF., Sept./Oct. 1997, at 184-86 (arguing that " $[\mathrm{t}]$ he state is not disappearing, it is disaggregating”).

209 See supra Part II. 
Thus, a cosmopolitan approach is ultimately moored to an expanded conception of how governments must operate in an interconnected world.

Finally, because it is based on this broader conception of governmental interests, a cosmopolitan approach avoids some of the concerns about democratic legitimacy raised by the substantive law method. Moreover, by treating choice of law as an a priori discussion of community definition and affiliation, cosmopolitanism rejects the undue emphasis on substantive rules that is the hallmark of the substantive law method. Yet cosmopolitanism, like the substantive law method, asks courts resolving multistate disputes to see themselves as international and transnational actors who are engaging in an international dialogue about legal norms. Accordingly, they must consider how best to construct a world system of law (and not just pursue parochial interests), and they may develop hybrid norms for resolving multistate disputes.

A cosmopolitan approach to international adjudication, therefore, allows courts to engage in a dialogue with each other concerning the appropriate definition of community affiliation and the appropriate scope of prescriptive jurisdiction. In addition, the approach asks courts to develop international norms, thereby harnessing the generative potential of international litigation. Treaties and other formal instruments of international lawmaking are cumbersome and slow to adjust to changing technologies or social conditions; international common law adjudication is far more dynamic. As a result, international private law litigation can serve public values by creating a forum for debates both about community affiliation and new common law international norms. ${ }^{210}$

Of course, such dynamism also raises important concerns. ${ }^{211}$ For example, one might fear that common law norm development will diminish the predictability of legal rules. Indeed, many actors would certainly sacrifice some dynamism in exchange for the ability to predict judicial outcomes more effectively. This concern may, however, be overstated for several reasons. First, as with all common law rules, the amount of uncertainty diminishes over time as areas of doctrine become more settled. Likewise, as courts develop norms for determining that certain activities establish community ties sufficient to jus-

\footnotetext{
${ }^{210}$ See, e.g., Martinez, supra note 15, at 444-48 (describing the importance of judgemade common law procedural doctrines in international and transnational litigation).

${ }^{211}$ The substantive law method also implicates these same concerns, and my discussion here largely tracks a similar discussion in Dinwoodie, supra note 160, at 571-75.
} 
tify the exercise of prescriptive jurisdiction, the uncertainty will diminish. Second, current choice-of-law analysis is already quite unpredictable and often arbitrary. ${ }^{212}$ Third, concerns about certainty in the commercial context are undermined by the fact that international commercial arbitration, which has few if any fixed substantive principles, has nevertheless been an extraordinarily popular means of resolving disputes. Finally, we must remember that it is not unprecedented for courts to introduce some uncertainty during the transition from one choice-of-law regime to another. For example, in the classic conflicts case of Neumeier $v$. Kuehner, ${ }^{213}$ the New York State Court of Appeals explicitly acknowledged that its rejection of a vested rights approach several years earlier had created uncertainty:

When ... we rejected the mechanical place of injury rule in personal injury cases because it failed to take account of underlying policy considerations, we were willing to sacrifice the certainty provided by the old rule for the more just, fair and practical result that may best be achieved by giving controlling effect to the law of the jurisdiction which has the greatest concern with, or interest in, the specific issue raised in the litigation. In consequence of the change effected-and this was to be anticipated-our decisions ... have, it must be acknowledged, lacked consistency.

Nevertheless, the court went out of its way to embrace the ad hoc, case-by-case approach it had used to construct the new choice-of-law regime. ${ }^{215}$ Significantly, the court emphasized that such common law development helps to uncover over time the appropriate values and policies to be weighed by courts, leading eventually to the formulation of new "rules of general applicability, promising a fair level of predictability." ${ }^{216}$ The ultimate outcome, according to the court, is worth the short-term cost.

Another concern, discussed previously, is that a court taking a cosmopolitan approach is behaving illegitimately because it is not ap-

${ }^{212}$ Cf. Kermit Roosevelt III, The Myth of Choice of Law: Rethinking Conflicts, 97 MiCH. L. Rev. 2448, 2449 (1999) ("Choice of law is a mess. That much has become a truism.”). For example, strict territorialism may encourage forum-shopping, with its concomitant lack of certainty.

213286 N.E.2d 454 (1972).

${ }^{214} I d$. at 457 (citations omitted).

${ }^{215}$ See id. (noting that the prior cases "enable us to formulate a set of basic principles that may be profitably utilized, for they have helped us uncover the underlying values and policies which are operative in this area of the law").

${ }_{216}^{21}$ Id. (citing Tooker v. Lopez, 249 N.E.2d 394, 403 (N.Y. 1969) (Fuld, C.J., concurring)). 
plying forum law. ${ }^{217}$ It must be remembered, however, that vested rights also often required courts to apply other states' laws; only the parochial understanding of governmental interests insists that forum law trump. Moreover, with an expanded understanding of governmental interests, there is no reason to fear that a court applying a cosmopolitan vision is necessarily unmoored from the long-term interest of the government to which the court owes its legal authority. Finally, it is important to remember that this cosmopolitan lawmaking is being engaged in not by unelected international regulators or bureaucrats but by national judges. Such judges come to the bench through domestic political or bureaucratic processes, and they are national citizens presumably influenced by national politics. Accordingly, " $[\mathrm{t}]$ he national courts that develop international norms are connected to a national legislative or political unit that can revisit apparent judicial over-reaching." ${ }^{218}$ By definition, then, even when a court incorporates a cosmopolitan conception into its framework, it is doing so as a local actor articulating a new (cosmopolitan) domestic norm in a multinational dispute.

Cosmopolitanism thus offers courts an opportunity to craft choiceof-law rules that reflect the realities of a world where people form multiple community affiliations that are not necessarily linked to physical geography. By considering these multiple affiliations, courts provide a forum for debate about the changing scope of prescriptive jurisdiction. Such debate can actually promote long-term international cooperation by providing incentives for other branches of government to negotiate international regulatory compromises. ${ }^{219}$ And by recognizing the long-term interests that states have in being part of an interlocking world order, courts can engage in dynamic, transnational lawmaking, developing and applying international, transnational, or hybrid norms to govern multistate disputes.

217 Supra Part II.B.

${ }^{218}$ Dinwoodie, supra note 160 , at 577.

${ }^{219}$ William Dodge sees this incentive as a reason to prefer interest analysis over vested rights. See William S. Dodge, Extraterritoriality and Conflict-of-Laws Theory: An Argument for Judicial Unilateralism, 39 HARV. INT'L L.J. 101, 105-06 (1998). He argues that in a world of concurrent jurisdiction, there will be conflicts arising from parochial application of forum law and that these conflicts provide useful incentives to negotiate. Id. at 106. A cosmopolitan approach offers similar benefits both because it permits (and promotes) concurrent jurisdiction and because it raises the conflict-of-laws questions to the surface rather than simply assuming a forum law default. 


\section{ARTiculating a CoSMOPOLITAN Vision OF RECOGNITION OF JUDGMENTS}

Just as with choice of law, a cosmopolitan vision of judgment recognition requires judges to see themselves as part of an international network of courts and to see the parties before them as potentially affiliated with multiple communities. Those various communities might legitimately seek to impose their norms on such affiliated parties. Thus, when faced with an enforcement decision regarding a foreign judgment, courts should not necessarily assume that their own local public policies block such enforcement. Instead, courts must undertake a nuanced inquiry concerning whether the affiliations of the parties render the original court judgment legitimate. Although the local policies of the forum country are not irrelevant, those policies should be weighed against the overall systemic interest in creating an interlocking system of international adjudication.

This is not so different from what U.S. courts already do in domestic cases raising judgment recognition issues. Indeed, the United States Supreme Court has long held that states cannot invoke public policy to refuse to enforce sister-state judgments. ${ }^{220}$ This is true even when the judgment being enforced would be illegal if issued by the rendering state. ${ }^{221}$

Of course, in the domestic context, the recognition of judgments has a constitutional dimension because of the Full Faith and Credit Clause. $^{222}$ Moreover, within a single, relatively homogenous country, the idea of one state enforcing another state's judgment does not seem quite so controversial because the legal variations among states are likely to be relatively minor. On the other hand, the Full Faith and Credit Clause derives from the Articles of Confederation, ${ }^{223}$ which were drafted when the colonies were less homogenous and more akin to separate nation-states than they are today.

${ }^{220}$ See, e.g., Baker v. Gen. Motors Corp., 522 U.S. 222, 233 (1998) (clarifying that there is no public policy exception to the full faith and credit due judgments).

${ }^{221}$ See supra note 95.

${ }^{222}$ U.S. CONST. art. IV, $§ 1$.

${ }^{223}$ The Articles of Confederation contained a provision similar to article IV, section 1: "Full faith and credit shall be given in each of these States to the records, acts, and judicial proceedings of the courts and magistrates of every other State." U.S. ARTICLES OF CONFEDERATION art. IV. For a concise history of full faith and credit, see Robert H. Jackson, Full Faith and Credit-The Lawyer's Clause of the Constitution, 45 COLUM. L. REV. 1 (1945). 
In any event, while the decision to enforce a foreign court's judgment will surely be less automatic, many of the same principles are still relevant. Most importantly, what we might call the "conflicts values" that underlie the Full Faith and Credit command should be part of the judgment recognition calculus. Thus, courts should acknowledge the importance of participating in an interlocking international legal system, where litigants cannot simply avoid unpleasant judgments by relocating. Indeed, in a cosmopolitan world, there is no need for inherent suspicion of foreign judgments. As in the choice-of-law context, deference to other courts will have long-term reciprocal benefits. And, particularly when the parties have no significant affiliation with the forum state, there is little reason for a court to insist on following domestic public policies in the face of such competing conflicts values.

This is not to say that foreign judgments should always be enforced. Even in a cosmopolitan system, one would expect that judges might sometimes interpose local public policies where they would not in the domestic state-to-state setting. But if we acknowledge the importance of the conflicts values effectuated by strong judgment recognition, we will necessarily reject the idea that, because a judgment could not have been issued by a court in the first instance, that court is simply unable to enforce the judgment. Instead, we will appreciate that enforcing a foreign judgment is fundamentally different from issuing an original judgment. Indeed, judgment recognition implicates an entirely distinct set of concerns about the role of courts in a multistate world.

In most areas of law, United States courts have generally invoked these conflicts values and enforced foreign judgments as a matter of comity. ${ }^{224}$ As far back as 1895, in Hilton v. Guyot, ${ }^{225}$ the U.S. Supreme Court made clear that comity "is the recognition which one nation allows within its territory to the legislative, executive, or judicial acts of another nation, having due regard both to international duty and convenience, and to the rights of its own citizens, or of other persons who are under the protection of its laws. ${ }^{226}$ The Second Restatement of Conflict of Laws codified this idea, noting that a "judgment rendered in a foreign nation ... will, if valid, usually be given the same effect as a

${ }^{224}$ See Mark D. Rosen, Exporting the Constitution, 53 EMORY L.J. 171, 176 (2004) (noting that, since the nineteenth century, "the United States has been at the vanguard of enforcing foreign judgments").

${ }^{225} 159$ U.S. 113 (1895).

${ }^{226}$ Id. at 164. 
sister State judgment.”227 Moreover, validity is based only on whether the court that rendered judgment had proper personal jurisdiction over the parties and utilized procedures that were not inherently unfair. ${ }^{228}$

In addition, while courts enforcing foreign judgments (as opposed to domestic ones) have applied a public policy exception to avoid enforcing particularly egregious rulings, the exception has been construed very narrowly. ${ }^{229}$ Accordingly, courts only refuse to enforce "where the original claim is repugnant to fundamental notions of what is decent and just in the State where enforcement is sought." ${ }^{230}$ Likewise, the United Nations Convention on the Recognition and Enforcement of Foreign Arbitral Awards and the Uniform Foreign Money-Judgments Recognition Act require that a U.S. court enforce a judgment or arbitral award unless there is fraud or if doing so would be repugnant to the public policy of the enforcing forum. ${ }^{231}$ Thus, in most recognition of judgments cases, "[c] ourts consistently have enforced foreign judgments even if they would have refused to entertain suit on the original claim on grounds of public policy." ${ }^{232}$ As Judge Cardozo observed: "We are not so provincial as to say that every solution of a problem is wrong because we deal with it otherwise at home." ${ }^{233}$

In stark contrast to this general policy of respecting foreign judgments, however, U.S. courts generally have assumed, at least where U.S. constitutional values seem to be at stake, that enforcing an "unconstitutional" judgment is itself a violation of the U.S. Constitution. As a result, courts have effectively imposed U.S. constitutional norms onto foreign disputes, even in circumstances where the dispute has little connection with the United States. ${ }^{234}$

${ }^{227}$ Restatement (SECOND) OF CONFLict OF LAWS, $\$ 117$ cmt. c (1971).

228 Id. $§ 92$.

${ }^{229}$ See Rosen, supra note 224, at 177-79 (surveying U.S. case law on enforcement of foreign judgments).

${ }^{230}$ RESTATEMENT (SECOND) OF CONFLICT OF LAWS, $\$ 117 \mathrm{cmt}$. c (1971).

${ }^{231}$ See, e.g., Convention on the Recognition and Enforcement of Foreign Arbitral Awards, June 10, 1958, 330 U.N.T.S. 38 (requiring courts to enforce the judgment or arbitral award unless there is fraud or if doing so would be repugnant to the public policy of the enforcing forum); UNIF. FOREIGN MONEY-JUDGMENTS RECOGNITION ACT $\S 4,13$ pt. II U.L.A. 58-59 (2002) (discussing situations where foreign judgments need not be recognized).

${ }^{232}$ Rosen, supra note 224, at 178-79.

${ }^{233}$ Loucks v. Standard Oil Co., 120 N.E. 198, 201 (1918).

${ }^{234}$ For an insightful critique of this practice, see Rosen, supra note 224, at 227-32. 
Consider, for example, the case of Telnikoff $v$. Matusevitch. ${ }^{235}$ This was a libel case between two British citizens concerning writings that appeared in a British newspaper. ${ }^{236}$ After a complicated sequence of proceedings in the United Kingdom, a jury ruled for the plaintiff and ordered damages, ${ }^{237}$ but Matusevitch moved to the state of Maryland and subsequently sought a declaration that the British libel judgment could not be enforced in the United States, pursuant to the First Amendment. ${ }^{238}$ The Maryland Supreme Court ultimately ruled that, because British libel law violates the speech-protective First Amendment standards laid out by the U.S. Supreme Court in New York Times Co. v. Sullivan ${ }^{239}$ and its progeny, the British judgment violated Maryland public policy and could not be enforced.

But there is no reason to think that the U.S. Constitution is necessarily implicated in such an enforcement action. First, it is debatable whether the simple enforcement of a judgment creates the requisite state action to implicate constitutional concerns. ${ }^{241}$ Second, with re-

235702 A.2d 230 (Md. 1997).

${ }^{236}$ See id. at 232-34 (summarizing the facts of the case).

${ }^{237}$ See id. at 233-35 (detailing prior proceedings).

${ }^{238}$ See id. at $235-36$.

239376 U.S. 254 (1964); see id. at 280 (holding that the First Amendment limits recovery for libel to false statements made with "actual malice-that is, with knowledge that it was false or with reckless disregard of whether it was false or not").

240 Telnikoff, 702 A.2d at 249, 251.

${ }^{241}$ In Shelley v. Kraemer, 334 U.S. 1 (1948), the U.S. Supreme Court ruled that the Equal Protection Clause precluded a court from enforcing a private, racially restrictive covenant. In so doing, the Court determined that, although the covenant itself was entered into by private actors who were not subject to the commands of the Fourteenth Amendment, the action by the courts in enforcing the covenant was sufficient state action to trigger constitutional scrutiny. Id. at 18-19. Shelley, therefore, appears to block judicial enforcement of a private agreement (or a foreign order) that would be unconstitutional. Indeed, courts, in refusing to enforce foreign "unconstitutional" judgments, have explicitly relied on Shelley. See, e.g., Yahoo!, Inc. v. La Ligue Contre Le Racisme Et L'Antisémitisme, 169 F. Supp. 2d 1181, 1189 (N.D. Ca. 2001) (citing Shelley), rev'd on other grounds, 379 F.3d 1120 (9th Cir. 2004), reh'g granted en banc, 399 F.3d 1010 (9th Cir. 2005). Since the time Shelley was issued, however, courts and commentators have backed away from the sweeping ramifications of Shelley. This is because, under Shelley's reasoning, any private contract that is being enforced by a police officer or court would be transformed into state action. See LAUREnCE H. TRIBE, AMERICAN CONSTITUTIONAL LAW 1697 (2d ed. 1988) (arguing that Shelley's approach, "consistently applied, would require individuals to conform their private agreements to constitutional standards whenever, as almost always, the individuals might later seek the security of potential judicial enforcement"). Although generations of legal realists and critical legal studies scholars have articulated similarly sweeping conceptions of state action, see Paul Schiff Berman, Cyberspace and the State Action Debate: The Cultural Value of Applying Constitutional Norms to "Private" Regulation, 71 U. ColO. L. REV. 1263, 1279-81 (2000) (surveying these critiques), courts have largely resisted Shelley and have limited 
gard to interstate harmony, a refusal to enforce the British libel judgment effectively imposes U.S. First Amendment norms on the United Kingdom. Such parochialism in judgment recognition, as in choice of law, is cause for concern. Third, while it is true that constitutional considerations could conceivably generate sufficient public policy reasons to refuse to enforce a judgment, the libel dispute in Telnikoff did not in any way implicate U.S. public policy because neither party had any particular affiliation with the United States at the time of the events at issue.

Thus, even if U.S. constitutional values or public policy considerations might sometimes require a court to refuse to enforce a judgment, there is no basis for a categorical rule preventing enforcement, and little reason to refuse to enforce an otherwise valid foreign judgment absent significant ties between the dispute and the United States. Instead, courts should take seriously the conflicts values that would be effectuated by enforcing the foreign judgment, weigh the importance of such values against the relative importance of the local public policy or constitutional norm, and then consider the degree to which the parties have affiliated themselves with the forum. Only then can courts take into account the multistate character of the dispute and the flexible nature of community affiliation in a cosmopolitan world.

\section{APPLYING THE COSMOPOLITAN Vision}

A cosmopolitan approach to choice of law and recognition of judgments yields a significantly different framework for analyzing the cases discussed in Part I. Although the ultimate result does not change in each instance, cosmopolitanism would affect the way in which judges view their task in considering cases with multinational dimensions. This Part therefore reconsiders each case in turn. ${ }^{242}$

\footnotetext{
its holding only to the context of racially restrictive covenants. Even in cases implicating the First Amendment, "with virtually no exceptions, courts have concluded that the judicial enforcement of private agreements inhibiting speech does not trigger constitutional review, despite the fact that identical legislative limitations on speech would have." Rosen, supra note 224, at 193; see also id. at 192-95 (discussing cases that have addressed the judicial enforcement of private contracts). Thus, it is not clear how robust Shelley still is and whether it would truly pose a constitutional bar in an action to enforce a foreign judgment. For further discussion of Shelley and its implications for judgment recognition, see Rosen, supra note 224, at 186-209.

${ }^{242}$ See supra Part I (introducing cases).
} 


\section{A. GlobalSantaFe Corp. v. Globalsantafe.com}

Rather than simply insisting on applying U.S. law, a court with a cosmopolitan vision of choice of law would ask whether the community affiliations of the parties in GlobalSantaFe. ${ }^{243}$ made it more appropriate to apply the law of South Korea or the law of the United States (or some combination of the two). At first glance, such an analysis might seem to produce a draw. GlobalSantaFe is a U.S. corporation, but Park is a South Korean citizen who did not even register the domain name in dispute with a U.S. registrar. ${ }^{244}$ Thus, even a tenuous, Internet-based contact with the United States is lacking.

Yet, relying on such literal "contacts" is a relic of territorialism (even when the contact in question is simply "visiting" a U.S.-based web server). Instead, a cosmopolitan vision looks to affiliation. Here, Park purposely registered the domain name of a newly-formed U.S. corporation, GlobalSantaFe, precisely because it was a newly formed corporation. ${ }^{245}$ Accordingly, this is not a case where someone registers a domain name for independent reasons, and the name just happens to be the same as that of some distant entity that was likely unknown to the registrant. Instead, Park was fully aware of the U.S. corporation and deliberately picked the name to take advantage of the confusion and then sell the name back to the corporation.

I will leave to others to discuss whether Park's activity should be illegal, and whether anti-cybersquatting laws are a good idea or not. ${ }^{246} \mathrm{I}$ note only that Park's actions were wholly aimed at a U.S. corporation based in the United States. On that basis, it seems that a court using a cosmopolitan perspective would apply U.S. trademark law to the dispute. Moreover, had the South Korean court adopted such a view, it would have enforced the original U.S. court judgment rather than set up a parochial battle of dueling injunctions. Indeed, if one viewed this as a judgment recognition case, under a cosmopolitan vision the South Korean court should first have acknowledged Park's voluntary affiliation with the United States and then enforced the U.S. court's judgment in order to avoid precisely the sort of judicial impasse that occurred here. Such is the importance of conflicts values.

243250 F. Supp. 2d 610 (E.D. Va. 2003).

244 See id. at 613 n.4 (noting that the domain name was registered in Korea).

${ }^{245}$ See id. at 616 (finding that the registrant "clearly" registered the domain name "after, and in response to" the merger announcement).

${ }^{246}$ See supra note 22 and accompanying text. 
Does that mean that the citizenship of the alleged trademark holder should always govern the choice-of-law decision? Not necessarily. First, as noted above, if Park had registered the name without any knowledge of, or intent to profit from, the U.S.-based corporate name, there would be no voluntary affiliation with the United States. Second, if GlobalSantaFe, even if incorporated in the United States, were based in South Korea or conducted substantial activities there, then South Korean trademark law might well apply since both parties would have meaningful affiliations with South Korea.

Moreover, even though a cosmopolitan choice-of-law vision reaches the same result as the district court in this particular case, it would not support the district court's notion that the location of the registry company has any bearing at all on the choice-of-law decision. $^{247}$ Such a focus territorializes Internet transactions in a particularly arbitrary way, given that very few people know the whereabouts of, or interact with, the registry for a top-level domain. And as a practical matter, emphasizing the physical location of the registry company means that, for the foreseeable future, all domain name disputes (at least those in the most popular ".com" or ".net" or ".edu” domains) would be resolved under U.S. law. Such a system, while creating a certain degree of uniformity, is unacceptably parochial. Indeed, if in the future we were to see the emergence of a popular top-level domain whose registries were located outside the United States, there would likely be substantial objection from U.S. trademark holders. Thus, a system that privileges the arbitrary location of registry companies is an invitation to long-term segmentation of the domain name system, with different legal rules governing different top-level domains. A cosmopolitan vision, in contrast, though it may at times be less predictable, at least holds the promise of developing long-term common law consensus about which nation's laws should apply to which types of disputes.

\section{B. Barcelona.com, Inc. v. Excelentisimo Ayuntamiento de Barcelona}

In contrast to GlobalSantaFe, the domain name dispute in Barcelona.com ${ }^{248}$ has far less connection to the United States. Here we have a Spanish citizen registering a domain name using the name of a

${ }^{247}$ See GlobalSantaFe, 250 F. Supp. 2d at 617 (relying on the fact that the registry company was located within the district).

248330 F.3d 617 (4th Cir. 2003). 
Spanish city to create a tourist portal for people visiting Spain. ${ }^{249}$ While it is true that Nogueras, the registrant, subsequently transferred the domain name to a nominally American corporation, the corporation appears to have been created solely to hold the registration and has no actual presence in the United States beyond a domain name registration and a post office box. ${ }^{250}$

A cosmopolitan vision of choice of law need not countenance legal formalisms such as the place of incorporation. Rather, the inquiry is focused on substantive community affiliations. Here, all the true principals in the case are in Spain, and the dispute concerns a web portal for tourists intending to visit Barcelona. These are indeed strong affiliations with Spain.

Therefore, a cosmopolitan vision would embrace the approach of the district court and at least use Spanish law to determine whether the City of Barcelona held a valid trademark in names containing the word Barcelona. In contrast, the Fourth Circuit panel applied U.S. trademark law, on the theory that the Spanish law should not be applied extraterritorially. ${ }^{251}$ When dealing with a globally interconnected communications system, however, the appellate court's conception of extraterritoriality is problematic because there is no way to avoid a ruling that will have some extraterritorial effect. The Fourth Circuit focused on the specter of Spanish trademark law being applied in a case involving a U.S. corporation ${ }^{252}$ (never mind the fact that the corporation was only formally a U.S. entity). But the Fourth Circuit's approach is equally extraterritorial, because it applies U.S. trademark law in a case involving a Spanish trademark holder, various Spanish parties, and a web portal for tourists to Spain.

Accordingly, the mere fact that some country's trademark law will be applied extraterritorially does not provide any solution to the choice-of-law problem. Indeed, it is precisely the existence of a reciprocal extraterritoriality problem that makes it a choice-of-law question in the first place. Thus, relying on territoriality is no solution. Instead, the court should have delved deeper, using choice-of-law principles to analyze the substantive community affiliations of the parties. ${ }^{253}$

${ }^{249} I d$. at 620 .

${ }^{250} I d$.

${ }^{251} I d$. at $626-28$.

${ }^{252} I d$. at 628.

${ }^{253}$ It is also worth noting that, at least in cases where both parties have a good-faith connection to a name, the domain name could be "shared," so that users typing in the 
Finally, although a discussion of how the insights of legal pluralism can inform conflict-of-laws is beyond the scope of this Essay, it is worth noting that there is a third set of community norms in this case: not just those of the United States and Spain, but also the norms articulated by the WIPO arbitrator in the first place. These norms are a product of the Uniform Dispute Resolution Policy (UDRP) promulgated by the Internet Corporation for Assigned Names and Numbers (ICANN) ${ }^{254}$ ICANN might be thought of as an Internet-based governing body, ${ }^{255}$ and arguably the U.S. court could have deferred to this nonstate community affiliation. On the other hand, one might think that ICANN lacks the democratic accountability necessary to be a legitimate governing body ${ }^{256}$ and that any tie between a website operator

domain name would be shown an introductory screen giving them the choice of which site they are seeking.

${ }^{254}$ See Barcelona.com, 330 F.3d at 621 ("Every domain name issued by Network Solutions, Inc. is issued under a contract, the terms of which include a provision requiring resolution of disputes through the UDRP. In accordance with that policy, the City Council filed an administrative complaint with ... WIPO, an ICANN-authorized dispute-resolution provider located in Switzerland.").

${ }^{255}$ See A. Michael Froomkin, Wrong Turn in Cyberspace: Using ICANN to Route Around the APA and the Constitution, 50 DUKE L.J. 17, 20 (2000) ("For almost two years, the Internet Corporation for Assigned Names and Numbers (ICANN) has been making domain name policy under contract with the Department of Commerce ...."); David G. Post, Governing Cyberspace, or Where Is James Madison When We Need Him? (June 1999), at http://www.temple.edu/lawschool/dpost/icann/comment1.html ("[N]otwithstanding the [U.S.] government's (and ICANN's) protestations to the contrary, this is about nothing less than Internet governance writ large."). Indeed, at the press conference convened in 1998 to unveil the Department of Commerce White Paper that led to the creation of ICANN, Becky Burr, Department of Commerce spokeswoman, stated:

We are looking for a globally and functionally representative organization, operated on the basis of sound and transparent processes that protect against capture by self-interested factions, and that provides robust, professional management. The new entity's processes need to be fair, open, and procompetitive. And the new entity needs to have a mechanism for evolving to reflect changes in the constituency of Internet stakeholders.

Press Release, Becky Burr, Associate Administrator, National Telecommunications and Information Administration's Office of International Affairs, Commerce Department Releases Policy Statement on the Internet Domain Name System (June 5, 1998), available at http://www.ntia.doc.gov/ntiahome/press/dnsburr.htm.

${ }^{256}$ For criticisms of ICANN from the perspective of democratic legitimacy and administrative transparency, see, for example, Froomkin, supra note 255, at 18; Jonathan Weinberg, ICANN and the Problem of Legitimacy, 50 DUKE L.J. 187, 188 (2000); Post, supra note 255. See generally Centre for Global Studies, Univ. of Vict., Enhancing Legitimacy in the Internet Corporation for Assigning Names and Numbers: Accountable and Transparent Governance Structures (Sept. 18, 2002), at http://www.markle.org/ downloadable_assets/icann_enhancelegitemacy.pdf. For similar criticisms of WIPO, see, for example, A. Michael Froomkin, Of Governments and Governance, 14 BERKELEY 
and ICANN is largely involuntary ${ }^{257}$ and therefore not a cognizable community affiliation. In any event, the existence of the WIPO arbitration in this case reminds us that nonstate entities may be an important source of norms and must at least be considered in any conflicts analysis.

\section{Yahoo!, Inc. v. La Ligue Contre Le Racisme Et L’Antisémitisme}

Like Barcelona.com, the Yahoo! case ${ }^{258}$ also raises a reciprocal problem of extraterritoriality. Yahoo! argued that the French judgment was an impermissible attempt by France to impose global rules for Internet expression. ${ }^{259}$ Yet, if France is not able to block the access of French citizens to proscribed material, then the United States will effectively be imposing First Amendment norms on the entire world. Again, the issue of extraterritoriality is inescapable.

So, how does a court adopting a cosmopolitan framework approach the question of whether to recognize the French judgment?

TECH. L.J. 617, 618 (1999):

As an international body all too willing to take up the reins of global governance, WIPO attempted to create global e-commerce friendly rules by a process that, left to itself, seemed likely to consist predominantly of meeting with commercial interest groups and giving little more than lip service to privacy and freedom of expression concerns.

For criticism of the UDRP system on the ground that the arbitration system is fundamentally biased in favor of trademark holders, see Michael Geist, Fair.com?: An Examination of the Allegations of Systemic Unfairness in the ICANN UDRP, 27 BROOK. J. INT'L L. 903, 903-13 (2002) (noting that the system is biased in favor of trademark holders); Michael Geist, Fundamentally Fair.Com? AN Update on Bias Allegations and THE ICANN UDRP 8 (2002), at http://aix1.uottawa.ca/ geist/fairupdate.pdf (updating study, responding to methodological criticisms, and stating that bias continues). All of these criticisms might be relevant in determining whether a court should consider or defer to norms articulated through the UDRP process.

${ }^{257}$ As Michael Froomkin describes:

Anyone who wishes to have a domain name visible to the Internet at large must acquire it from a registrar who has the right to inscribe names in an ICANN-approved domain name registry. ICANN determines which registries are authoritative. This power to make and break registries allows ICANN to require registries (and also registrars) to promise to subject all registrants to a mandatory third-party beneficiary clause in which every registrant agrees to submit to ICANN's UDRP upon the request of aggrieved third parties who believe they have a superior claim to the registrant's domain name.

A. Michael Froomkin, ICANN's "Uniform Dispute Resolution Policy"-Causes and (Partial) Cures, 67 BRoOK. L. Rev. 605, 612 (2002).

${ }^{258} 169$ F. Supp. 2d 1181 (N.D. Ca. 2001), rev'd on other grounds, 379 F.3d 1120 (9th Cir. 2004), reh'g granted en banc, 399 F.3d 1010 (9th Cir. 2005).

${ }^{259}$ Supra note 89 and accompanying text. 
To begin, we must acknowledge that this is a difficult case. To the extent that local public policies should have any valence in an international judgment recognition decision, here the U.S. public policy is particularly strong. Not only is the First Amendment a constitutional command, but it goes to the heart of American self-identity and arguably helps to define American democracy. Moreover, unlike in the Telnikoff case discussed above, ${ }^{260}$ Yahoo! is a U.S. corporation based in the United States. Thus, Yahoo!'s entitlement to First Amendment protection is far stronger than was Matusevitch's.

On the other hand, in weighing the relevant conflicts values, it becomes clear that this case is not merely a matter of France simply imposing its norms on an entity with no affiliation in France. Rather, as Joel Reidenberg has argued, ${ }^{261}$ Yahoo! is a sophisticated, multinational operator, with a business plan aimed at reaching web users worldwide, ${ }^{262}$ a marketing strategy touting its "global footprint," a French subsidiary in which it owns a seventy percent ownership stake. ${ }^{264}$ Indeed, Yahoo! exerted substantial control over this subsidiary, dictating some of the links and content of the French site and requiring the subsidiary to maintain links to its U.S.-based site. ${ }^{265}$ Moreover, Yahoo! routinely profiled French users in order to target them with advertisements written in French. ${ }^{266}$ Given these efforts to take advantage of the French market and affiliate itself with France, Yahoo! has less cause for complaint concerning France's "extraterritorial" judgment.

${ }^{260}$ Supra text accompanying notes 235-240.

${ }^{261}$ Reidenberg, supra note 82, at 267.

262 See YAHOO! INC., 1999 ANNUAL REPORT 2 (2000) [hereinafter YAHOO! 1999 ANNUAL REPORT] ("Yahoo! Inc.... is a global Internet communications, commerce and media company that offers a comprehensive branded network of services to more than 120 million users each month worldwide."), available at http://www.sec.gov/ Archives/edgar/data/1011006/0000912057-00-014598-d1.html.

${ }^{263}$ See Press Release, Yahoo! Inc., Yahoo! Reports Fourth Quarter, Year End 2000 Financial Results (Jan. 10, 2001) ("Yahoo! remained committed to broadening its global footprint and maintaining a leadership position worldwide."), available at http://docs.yahoo.com/docs/pr/4q00pr.html.

${ }^{264}$ YAHOO! 1999 ANNUAL REPORT, supra note 262, at 5.

265 See Yahoo! France License Agreement, art. 3 (1996), in YAHOO! INC., 1996 ANNUAL REPORT exhibit 10.33, at 141-61 (1997) (setting forth the terms of the licensing agreement between Yahoo! Inc. and Yahoo! France), available at http://www.sec. gov/Archives/edgar/data/1011006/0000912057-97-011353.txt.

${ }^{266}$ See T.G.I. Paris, May 22, 2000, available at http://www.juriscom.net/txt/jurisfr/ cti/tgiparis20000522.htm (describing Yahoo!'s practice of profiling and targeting French users). 
Thus, the Yahoo! case falls within two extremes. At one pole is Telnikoff, in which the relevant community affiliations of both the parties and the dispute were exclusively British, and therefore enforcing the British libel judgment would be appropriate. At the other pole is a hypothetical case in which a small, local website based in the United States is prosecuted in France solely because of material available on its website. The company's utter lack of community affiliation with France would likely mean that the French judgment should not be enforced in the United States. In that instance, the strong First Amendment values would outweigh the need to enforce the judgment in order for the recognition court to remain a cooperative member of an international judicial community. In Yahoo!, there is both significant affiliation with the United States and significant affiliation with France. In the end, under a cosmopolitan approach, I think that the extent of Yahoo!'s business activities abroad justify the French judgment and should make it enforceable in the United States. But regardless of the final outcome, it is clear that courts could not simply cite the First Amendment and refuse to enforce a foreign judgment without actually considering the conflicts values implicated by the enforcement decision.

\section{CONCLUSION}

In a case decided in 2004, F. Hoffman-La Roche Ltd. v. Empagran S.A., ${ }^{267}$ the U.S. Supreme Court refused to apply the Sherman Act extraterritorially to regulate alleged anticompetitive activity that took place overseas, at least to the extent that the relevant harm was suffered by foreign plaintiffs. Although the applicable statutory provision was ambiguous concerning the appropriate extraterritorial application of U.S. antitrust laws, the Court refused to interpret the statute to reach foreign anticompetitive conduct causing only foreign injury. Justice Breyer, writing for the Court, opined that, "if America's antitrust policies could not win their own way in the international marketplace for such ideas, Congress, we must assume, would not have tried to impose them, in an act of legal imperialism, through legislative fiat." ${ }^{268}$

While the facts of Hoffman-La Roche are not necessarily analogous to the three cases discussed in this Essay, ${ }^{269}$ the Court's statement

\footnotetext{
${ }^{267} 124$ S. Ct. 2359 (2004).

${ }^{268}$ Id. at 2369.

${ }^{269}$ The Barcelona.com case, however, is somewhat similar because in that case, as in
} 
about "legal imperialism" is nevertheless instructive. In a highly interdependent world, concerns about legal imperialism may be as significant as concerns about military, political, or cultural imperialism. And while it is unrealistic (and perhaps unappealing) to expect international harmonization of legal norms, a cosmopolitan approach would at least allow judges to evaluate multiple community affiliations while developing choice-of-law rules as part of a joint transnational enterprise.

Conflicts analysis, of course, is one way in which courts and commentators attempt to create ordering principles for evaluating the intractable problems that arise in a world of transnational communication, commerce, and affiliation. Thus, the first step is for courts to take this analysis seriously and actually use conflicts principles in cases raising multistate concerns. Instead of simply applying a domestic law to a transnational dispute, courts must analyze the degree to which that domestic law should be applied to the dispute. Indeed, regardless of the precise rubric used for resolving conflicts cases, the initial point is that courts cannot avoid at least considering the conflicts values that are potentially implicated. Otherwise, we risk creating a completely segmented international legal system, whereby jurisdictions compete to apply their laws extraterritorially with no limits and no analysis.

In addition, the particular rubric for deciding conflicts cases matters. This is because, at root level, conflicts rules reflect our changing definitions of community affiliation. The conflicts analysis always asks: when is it legitimate for one community to impose its norms on a dispute with links to other communities? Thus, conflict of laws is a terrain of engagement, where the crucial problems of globalization must be worked out over time.

In an era of global interaction-with its rapid movement of people, money, ideas, goods, and services-a conflicts jurisprudence based solely on the territorial location of key events is unduly limited and cannot hope to capture the variety of nonterritorial affiliations people and corporations actually form. Likewise, conflicts rules based on parochial preferences for forum law are apt to turn into legal imperialism unless one's idea of a government's self-interest is expanded to include an interest in being a cooperating member of the global community. And though it makes sense to allow courts more freedom to craft common law compromises in multistate cases, the question of

Hoffman-La Roche, the actors and nearly all the significant actions took place outside the United States. 
community affiliation is too important to be folded into the substantive legal issues without separate analysis. Finally, in determining whether to recognize foreign judgments, courts must take into account that parties with foreign affiliations might appropriately be subject to foreign court decisions even if such judgments do not accord with U.S. law or public policy. Thus, courts seeing themselves as part of an interlocking world system cannot simply assume that local preferences necessarily prevail.

A cosmopolitan vision of conflict of laws aims to respond to these imperatives. By focusing on community affiliation rather than territoriality, cosmopolitanism attempts to turn the legal gaze to the reality of global interaction rather than simply the formal contacts with a geographical location. Moreover, given such multiple community affiliations, there is no reason to privilege forum law. Rather, cosmopolitanism recognizes, as many scholars of law and globalization have, that we do not live in a world where states can effectively pursue their own short-term self-interest with single-minded devotion. Because states are inevitably embedded in an international system, they internalize the aspirations and disciplining norms of that international system and have an important interest in being a cooperative member of a global community. Yet, given that it is both practically unlikely and normatively undesirable to create a single overarching global law, courts must engage in an ongoing, nuanced discussion of conflict-oflaws principles in order to accommodate both the particularities of each community and the need to regulate multiple communities effectively. Such nuanced analysis will consider community affiliation, the functional needs of the transnational system, and the possibility of developing hybrid norms for cases that touch multiple normative communities. And, in considering judgments issued by courts abroad, judges must analyze the importance of long-term conflicts values and not just reflexively rely on local norms.

There is much more work to be done, of course, to develop stable legal principles concerning how best to calibrate community affiliation for the purpose of resolving difficult conflict-of-laws cases. Part of the point of a cosmopolitan approach, however, is to allow transnational adjudication (and possibly diplomacy) ${ }^{270}$ to work out conflicts norms over time. Only through ongoing discussion of how to analyze community affiliation in a global era will a truly transnational legal sys-

${ }^{270}$ See, e.g., Dodge, supra note 219, at 106 (arguing that a choice of law system that acknowledges multiple concurrent jurisdiction may help spur international harmonization efforts by other branches of government). 
tem be born. Finally, though this Essay has focused on norms embodied by official state-sanctioned entities, a comprehensive analysis of conflict of laws embraces the insights of legal pluralism and considers nonstate norm-generating communities, as well as the degree to which those norms should be analyzed for their persuasive power in conflicts settings.

Nevertheless, for now it is enough simply to move the discussion towards a different set of criteria for analyzing transnational conflicts questions. By acknowledging multiple community affiliations and a broader set of state interests, we are less likely to engage in legal imperialism and more likely to consider the ways in which all states inevitably have a stake in a functioning transnational system. As in Young's account of the "unoppressive city,"271 we must consider a conflicts approach that permits "unassimilated otherness," while still emphasizing cooperation, accommodation, and global interaction. And though we are unlikely ever to attain such a lofty set of goals, we can at least take an important step by adopting legal rules that seriously engage the increasingly cosmopolitan world in which we live.

${ }^{271}$ Young, supra note 183, at 317. 